\title{
Occurrence, Origin and Health Hazards of High Fluoride Waters in the Western Part of the Neogene Sedimentary Basin in Opole Province, Poland
}

\author{
Lidia Razowska-Jaworek*, Joanna Cudak \\ Polish Geological Institute-National Research Institute, Upper Silesian Branch, ul. Królowej Jadwigi 1 41-200 Sosnowiec, Poland
}

Received December 19, 2021; Revised January 22, 2022; Accepted February 20, 2022

\section{Cite This Paper in the following Citation Styles}

(a): [1] Lidia Razowska-Jaworek, Joanna Cudak, "Occurrence, Origin and Health Hazards of High Fluoride Waters in the Western Part of the Neogene Sedimentary Basin in Opole Province, Poland," Universal Journal of Geoscience, Vol. 9, No. 1, pp. 1 - 20, 2022. DOI: 10.13189/ujg.2022.090101.

(b): Lidia Razowska-Jaworek, Joanna Cudak (2022). Occurrence, Origin and Health Hazards of High Fluoride Waters in the Western Part of the Neogene Sedimentary Basin in Opole Province, Poland. Universal Journal of Geoscience, 9(1), 1 - 20. DOI: 10.13189/ujg.2022.090101.

Copyright $\mathrm{C} 2022$ by authors, all rights reserved. Authors agree that this article remains permanently open access under the terms of the Creative Commons Attribution License 4.0 International License

\begin{abstract}
High fluoride content exceeding permissible limits for drinking water and causing numerous incidents of fluorosis disease in the population of Nysa town was the reason for the closure of the deepest wells in the western part of the Neogene groundwater basin Paczków-Niemodlin in the Opole region in Poland. Hydrochemical studies conducted by the Polish Geological Institute - National Research Institute resulted in the recognition and extent of fluoride anomaly in the groundwater extracted from the Neogene basin in southern Poland. The studies provided a comprehensive recognition of hydrogeological and chemical conditions of the aquifer located in the Neogene basin characterized by a series of fine-grained sands within a series of clays. The content of fluoride in groundwater is high; the average is $2.1 \mathrm{mg} / \mathrm{L}$, maximum value reached $11.5 \mathrm{mg} / \mathrm{l}$, exceeding several times the permissible limit for drinking waters $(1.5 \mathrm{mg} / \mathrm{L})$. The main objective of this study was to determine the source of high concentrations of fluoride in groundwater in the western part of Paczków-Niemodlin basin where the highest concentrations were observed. The investigations confirmed the increase in fluoride content with the decreasing altitude of the aquifers. Various factors that may form the chemistry of these groundwater were analyzed. The most probable source of high fluoride content in groundwater in this basin is their long-term contact with Precambrian and Palaeozoic igneous and metamorphic rocks containing fluorine-rich minerals along with the location near large fault zones, which may be
\end{abstract}

privileged water flowpaths from greater depths.

Keywords Hydrochemistry, Groundwater, Fluoride, Fluorosis, Poland

\section{Introduction}

Excessive fluoride consumption can lead to dental and skeletal fluorosis, a disease that causes mottling of the teeth and calcification of ligaments [16]. Long-term ingestion of fluoride-rich drinking water may cause crippling bone deformities, cancer, decreased cognitive ability, lower intelligence quotient and develop mental issues in children.

The presence of fluoride in concentrations exceeding the limit values for drinking water is a problem in many countries around the world, particularly in India [36], Turkey [27], Argentina [1], Korea [19], Mexico [38], China [43], Iran [11], Pakistan [15] and many African countries (e.g. Ethiopia, Uganda, Kenya, Tanzania) [17, 37]. In Europe, rather deficiency of fluoride in drinking water prevails, but in the Nordic countries, in the granitic aquifers, an excess of fluoride has also been observed [8], as well as in Italy [39]. Most of these studies include the detailed description of the spatial distribution of fluoride in groundwater and health hazard. The average fluoride content in groundwater ranges from 0.1 to $0.2 \mathrm{mg} / \mathrm{l}$ and typically does not exceed $1 \mathrm{mg} / 1$ [41]. The origin of 
fluoride anomalies is not clearly explained.

The well-known F-containing minerals are, fluorite $\left(\mathrm{CaF}_{2}\right)$, fluoroapatite $\left(\mathrm{Ca}_{5}\left(\mathrm{PO}_{4}\right)_{3} \mathrm{~F}\right)$, micas, amphiboles, cryolite $\left(\mathrm{Na}_{3} \mathrm{AlF}_{6}\right)$, villiaumite $(\mathrm{NaF})$ and topaz $\left(\mathrm{Al}_{2}\left(\mathrm{SiO}_{4}\right) \mathrm{F}_{2}\right)$ are considered as the most abundant minerals which occur in most rocks and sediments $[9,14]$. Moreover micas and amphiboles may have $\mathrm{F}$ incorporated in their crystal lattices. Fluoride minerals such as fluorite and cryolite are not readily soluble in water under normal pressure and temperature. But under alkaline conditions and range of specific conductivity between 750 and $1750 \mu \mathrm{S} / \mathrm{cm}$, dissolution rate of fluorite increases [35]. Granitic rocks which are a typical source of fluoride rich liquids contain fluorine ranging between 500 and 1400 $\mathrm{mg} / \mathrm{kg}$ [21], which is much higher than any other rock type. The weathering of these rocks results in increased fluoride content in groundwater. Longer residence time in aquifers with fractured fluoride rich rocks enhances fluoride levels in the groundwater. Laboratory studies conducted by Chae et al. [9] showed that leaching of fluoride from granitic rocks contributed 6 to $10 \mathrm{mg} / \mathrm{l}$ of fluoride to water.

The prevalence and trends in the prevalence of fluorosis across Europe are difficult to ascertain because of the complexity and inaccuracy in comparing studies of differing methodology carried out in the various countries. However, there is an urgent need for researchers in Europe and elsewhere to adopt a standardized approach to the measurement of fluorosis [40].

Consumption of fluoride higher than the optimum level is the main reason for dental fluorosis. Ayoob and Gupta [4] estimated that around 200 million people, from among 25 nations all over the world are under the dreadful fate of fluorosis. In India 6 million children are evaluated to have serious health problems due to consumption of fluoride contaminated water $[2,12]$. More than 8 million people in Ethiopia are exposed to elevated concentration of fluoride [29]. The health outcome by consuming fluoride at different concentrations was given by Dissanayake [12] i.e. when fluoride concentration in drinking water is below 0.5 $\mathrm{mg} / \mathrm{L}$ it causes dental carries; fluoride between 0.5 to 1.5 $\mathrm{mg} / \mathrm{L}$ results in optimum dental health; 1.5 to $4 \mathrm{mg} / \mathrm{L}$ causes dental fluorosis; 4 to $10 \mathrm{mg} / \mathrm{l}$ induces dental and skeletal fluorosis while fluoride above $10 \mathrm{mg} / \mathrm{L}$ results in crippling fluorosis.

The aim of this paper is to describe the occurrence, origin and health effect of high fluoride content in the western part of the Neogene groundwater basin Paczków-Niemodlin. In these studies the concentration and spatial distribution of fluoride along with the hydraulic and hydrochemical processes in the confined aquifers were investigated. This paper provides the data for the local decision makers for sustainable water management and protection as well as international researchers for better understanding the processes leading to enrichment of fluoride in groundwater.

\section{Materials and Methods}

\subsection{Study Area and Geological Settings}

The Neogene groundwater basin Paczków-Niemodlin, which covers an area of approximately $740 \mathrm{~km}^{2}$, located in the southern part of the province of Opole (Fig.1) is one of the main groundwater basins (MGWB) in Poland [24]. This area is mostly of an agricultural and partly of an urban land use category with the main town of Nysa. The climate of this region is classified as cold without dry season, with warm summers and with an annual average temperature of 8.7 C and annual rainfall of $639 \mathrm{~mm} \mathrm{[33].}$

The study area is located in the eastern part of the Fore Sudetic block, composed of Proterozoic and Early Palaeozoic metamorphic rocks and Carboniferous granites (Fig. 1C) covered by the Cretacerous (Fig. 1C), Neogene (Fig. 1B) and the Quaternary sediments. The western part of the area is situated in the contact zone of two tectonic units: Fore Sudetic and Sudetic Block [6]. The southern border is a fault zone which extends diagonally through the north-eastern part of the area. In the south-western part of this area metamorphic rocks: biotite and biotite-silimanite gneisses, mica schists, amphibolites, quartzites, crystalline limestones, erlanes as well as granitoids are present on the surface.

Metamorphic rocks were formed during amphibolite facies alteration of sandstones, mudstones with limestone intercalates by volcanic rocks. The Proterozoic and Early-Late Palaeozoic rock units are folded and trend SW-NE with beddings dipping 50-80 ${ }^{\circ} \mathrm{SE}$. The formation of the granitoid massif is associated with the Asturian phase. The gneiss migmatization has been correlated with the thermal influence of granitoid magma [28].

The Neogene period was marked by block-type tectonic movements, occurring in several stages. As a result, the Sudetes were raised and a system of stair blocks descending to the ditches of Paczków and Kędzierzyn was created [7]. 

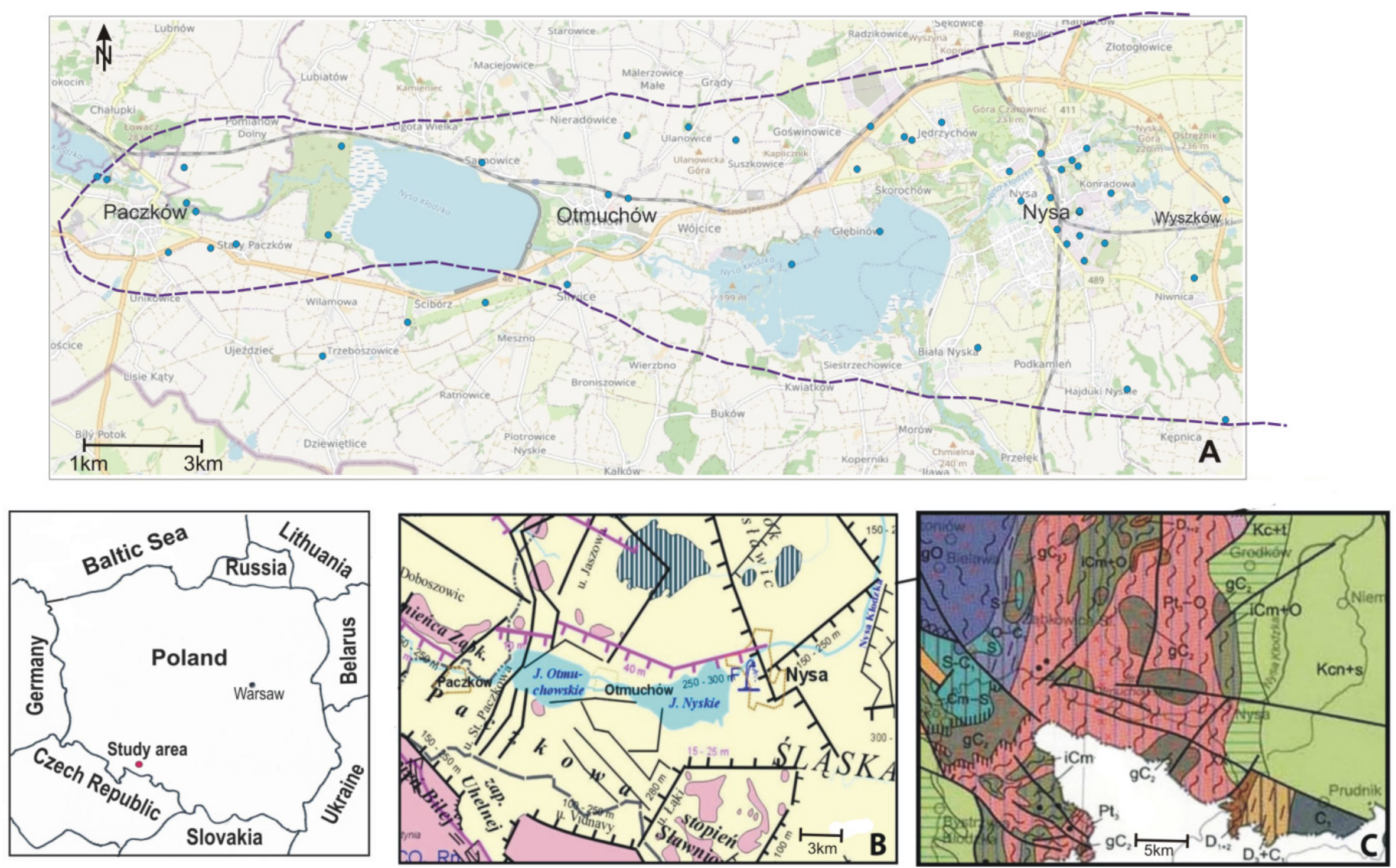

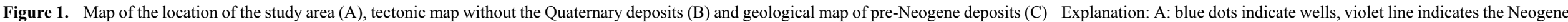

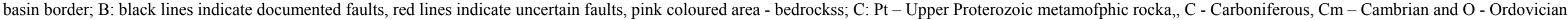
igneous rocks), $\mathrm{Kc}-$ Cretacerous sandstones, limestones and marls 
m a.s.l.

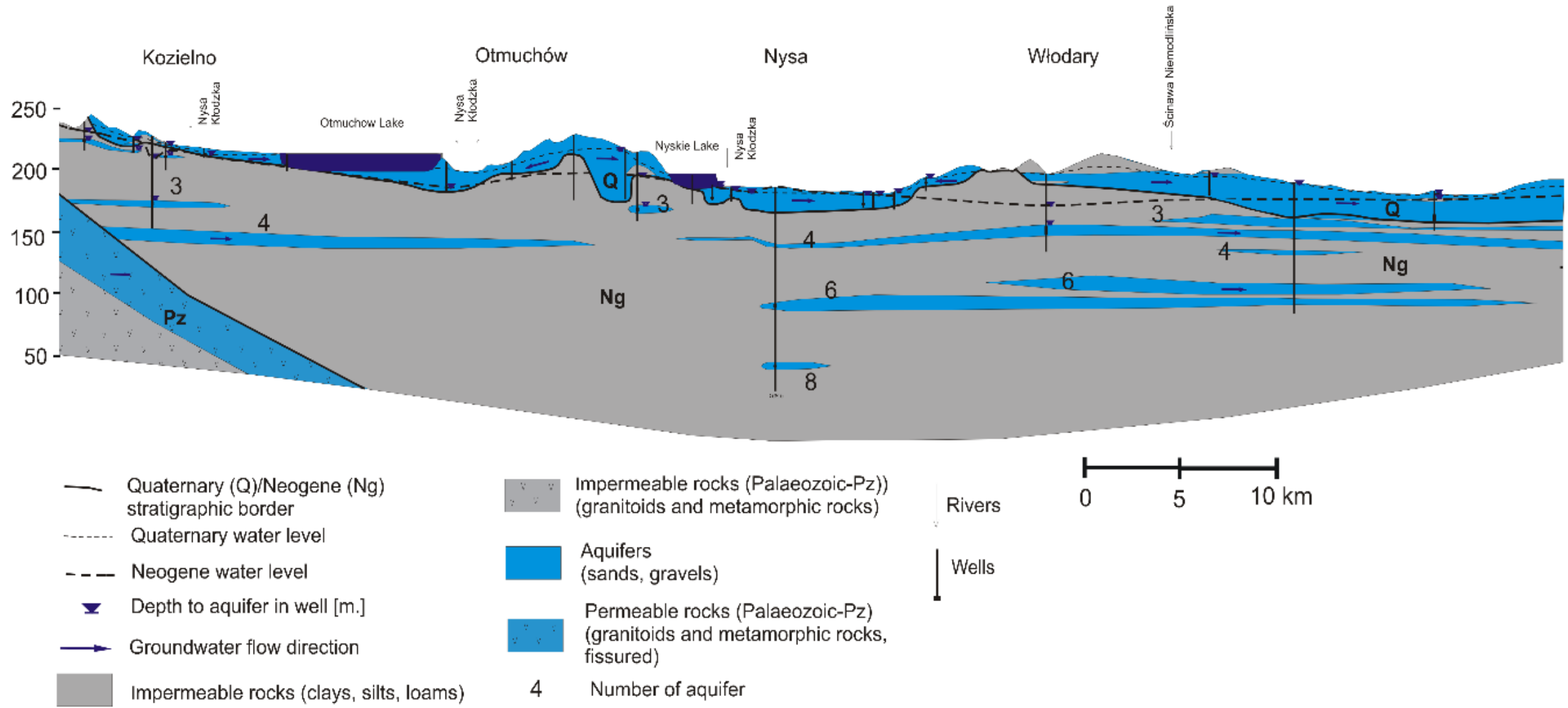

Figure 2. Schematic hydrogeological cross-section of the western part of the Neogene basin (after Razowska-Jaworek et al. 2013) 
The Neogene sediments are present almost throughout the area and their maximum thickness reaches $450 \mathrm{~m}$ [13]. This is a big, sedimentary basin comprising alternating lithological units (Fig. 2). The diverse geological structure of the Neogene formations in this region results from the fact that these sediments were formed in separate palaeogeographic units, and their sedimentation took place in different cycles. Complicated tectonic structures in which the Neogene formations have been deposited cause significant differences in the formation and the thickness of these sediments. The sedimentation processes were accompanied by intense tectonic processes, which led to the formation of a latitudinal sinkhole called the Paczków Ditch [6].

The main unit is the Miocene series formed as a coarse clay-silt complex, with sandy interfaces and inserts of brown coal, kaolin clay and loam with siderites, and reaching a thickness of up to $190 \mathrm{~m}$. Often the profile begins with the level of sands and quartz gravel with single lidites, quartz and marcasite covered by a fleshy complex of loam with inserts of silt, sand or sand with gravel. In the area of the Paczków Ditch, sand and sand-gravel sedimentation is more prevalent than clay sedimentation. In the southern part of the Ditch, at the extension of the estuary to the ditch of the Sudeten rivers, the material is coarse-grained sand-gravel. Layers of alluvial cones in clay deposits are present in this area. The axis of the local bay of the Miocene series stretches from Otmuchów, through Nysa and Wawrzynowice (Fig. 1B). Dyjor [13] believed that these formations were inflow cones, sprinkled by rivers flowing from the Sudetes, with lenses of clay or sandy sapropelites, brown coal, and large amounts of lignites (river floods).

\subsection{Hydrogeology}

The study area belongs to the left-bank of Odra river basin and is drained by the Nysa Kłodzka River. In terms of hydrography, the presented area is particularly diversified, as it covers the section of the Nysa Kłodzka River basin, which has been significantly changed by the construction of dams and retention reservoirs. There are two retention reservoirs in the study area: Otmuchów and Nysa reservoir (Fig. 1A). A surface public water intake for the town of Nysa and surrounding settlements was built on the Biała Głuchołaska River, following the closure of the Neogene wells due to the fluoride contamination.

There are four main aquifers in the research area: Quaternary, Neogene, Cretaceous and the Palaeozoic-Proterozoic complex. The Quaternary is generally present throughout the study area, forming one to three aquifers of varying thickness.

The occurrence of waters in the Neogene formations is related to the layers of sands, mainly fine-grained, within the clays. The waters in the Neogene formations occur throughout the studied area. The average conductivity coefficient is $1.2 * 10^{-4} \mathrm{~m} / \mathrm{s}$, and the thickness of the aquifers ranges from 0.5 to 72 meters [33]. The Neogene occurs both in the uplands and in tectonic ditches within the Fore-Sudetic Block, and its depth reaches $250 \mathrm{~m}$ in the western part of the area. In the western part, beneath the Quaternary and Neogene deposits Palaeozoic-Proterozoic rocks occur. The Quaternary and Neogene aquifers may lateral contact the Palaeozoic-Proterozoic aquifer developed in fractured shales, quartzites, gneisses and crystalline limestones, occurring in the southern part of the area [13]. The analysis of lithological profiles of wells and boreholes showed a high variability of the lithology of Neogene sediments.

Table 1. Aquifers in the Neogene groundwater basin "Paczków-Niemodlin"

\begin{tabular}{|c|c|c|c|c|c|}
\hline $\begin{array}{l}\text { Aquifer } \\
\text { No. }\end{array}$ & $\begin{array}{c}\text { Elevation of the } \\
\text { aquifer } \\
\text { [m a.s.l. }] \\
\end{array}$ & Stratigraphy & Lithology & $\begin{array}{c}\text { Depth of the } \\
\text { aquifer } \\
\text { [m] } \\
\end{array}$ & Wells No. \\
\hline 1 & $>240$ & \multirow{2}{*}{ Neogene, Pliocene } & \multirow{2}{*}{$\begin{array}{l}\text { Sands, gravels } \\
\text { coarse-grained }\end{array}$} & \multirow{2}{*}{$15-65$} & 37 \\
\hline 2 & $240-210$ & & & & 28 \\
\hline 3 & $210-160$ & \multirow{2}{*}{$\begin{array}{c}\text { Neogene, } \\
\text { Miocene, Sarmatian }\end{array}$} & \multirow{2}{*}{$\begin{array}{l}\text { Sands, quartz-feldspar, } \\
\text { medium-grained }\end{array}$} & \multirow{2}{*}{$8-125$} & $1,6,7,11,12,13,14,34,57$ \\
\hline 4 & $160-140$ & & & & $20,21,23,51,56,61,115$ \\
\hline 5 & $140-120$ & \multirow{2}{*}{$\begin{array}{l}\text { Neogene, } \\
\text { Miocene } \\
\text { Sarmatian }\end{array}$} & \multirow{2}{*}{$\begin{array}{l}\text { Sands, quartz-feldspar, thin } \\
\text { layers of limestones, marls }\end{array}$} & \multirow{2}{*}{$75-113$} & 43 \\
\hline 6 & $120-90$ & & & & $47,49,52$ \\
\hline 7 & $90-60$ & \multirow{2}{*}{$\begin{array}{l}\text { Neogene, } \\
\text { Miocene, } \\
\text { Sarmatian }\end{array}$} & \multirow{2}{*}{$\begin{array}{c}\text { Sands, muds, dark mica, } \\
\text { lenses of clay and brown } \\
\text { coal, touchstones, quartz, } \\
\text { markasite }\end{array}$} & \multirow[b]{2}{*}{$103-165$} & 48,53 \\
\hline 8 & $60-30$ & & & & 39,40 \\
\hline 9 & $30--5$ & $\begin{array}{c}\text { Neogene, } \\
\text { Miocene, Sarmatian }\end{array}$ & $\begin{array}{l}\text { Sands, muds, dark mica, } \\
\text { quartz, lenses of clay }\end{array}$ & $140-160$ & 41,50 \\
\hline 10 & $<-5$ & $\begin{array}{l}\text { Neogene, } \\
\text { Miocene, } \\
\text { Badenian }\end{array}$ & $\begin{array}{l}\text { Sands, muds, dark mica, in } \\
\text { bottom part marls, limestones }\end{array}$ & $>175$ & 42 \\
\hline
\end{tabular}


Based on the information from the HYDRO database [18] and the Geological Map of Poland [5, 7, 28] some of basin characteristic features can be presented here (Table 1). The upper aquifers (1 and 2) are discontinuous, the material is coarse sand and gravel. In the aquifers 3 and 4 usually various-grain sands, quartz-feldspar, interbedded with green and blue clays in the upper part prevails. In aquifers 5 and 6 , various-grain sands and quartz-feldspar are interbedded with lime-marly material. Muddy-sandy formations of aquifers 7-9 are abundant, rich in dark mica, and lenses of clay or sandy sapropellites, brown coals, sometimes large amounts of lignites. The composition of the aquifer 10 is similar to 7-9, but in the lower part of the aquifer carbonate sediments (limestone and marls) as well as sandstone occur. The aquifers are confined for the most part of the study area. The aquifers are mostly recharged through overlaying clay and silt strata and in contact zones with the Quaternary aquifer.

\subsection{Approach and Methods}

During previous hydrogeological studies of the Neogene basin the authors observed an elevated fluoride concentration in waters $[30,31,32]$. The preliminary results were published in 2009 [32], but later, in 2012-2013 the most important study was conducted in this area [33], a project which aimed the protection of aquifers in the Neogene basin Paczków-Niemodlin was a complex study. The hydrogeology and hydrogeochemistry of this basin included a hydrogeological mapping and modelling which covered an area of $2,048 \mathrm{~km}^{2}$. A simultaneous series of measurements of the water table was carried out in hydrogeological wells and in dug wells. Information on 274 wells (abstractions, water resources) was collected and updated. New, significant data was obtained, what changed the previous assumptions and conclusions.

The Polish Geological Institute-National Research Institute conducts research on the chemical status of groundwater as a part of diagnostic and operational monitoring in Poland in this area. Two wells have been observed within this basin, in Nysa and in Skoroszyce. The results of water level measurements and chemical analyses performed for these monitoring points were also taken into account during this study [25].

\subsection{Physicochemical and Stable Isotopes Analyzes}

The results of physicochemical analyses of groundwater which were performed during previous studies for active wells and monitoring points were collected. A total of 29 water samples were taken, $\mathrm{pH}$ was measured in the field along with EC (specific electric conductance) and temperature. Groundwater samples were field - filtered through a $0.45 \mu \mathrm{m}$ filters and filled into acid-washed bottles and acidified. Analyses of the chemical composition of water were performed at the Chemical Laboratory of the Polish Geological Institute in Warsaw. Water samples were analysed for major and minor dissolved chemical constituents $\left(\mathrm{Ca}, \mathrm{Mg}, \mathrm{Na}, \mathrm{K}, \mathrm{NH}_{4}, \mathrm{Fe}, \mathrm{Mn}, \mathrm{Sr}, \mathrm{As}, \mathrm{Al}, \mathrm{Ba}, \mathrm{Pb}\right.$, $\mathrm{Zn}, \mathrm{Cd}, \mathrm{Ni}, \mathrm{Co}, \mathrm{Cu}, \mathrm{Li}, \mathrm{HCO}_{3}$, and $\mathrm{SiO}_{2}$ ) by atomic absorption spectometry; $\mathrm{SO}_{4}, \mathrm{NO}_{2}, \mathrm{NO}_{3}, \mathrm{Cl}, \mathrm{Br}, \mathrm{HPO}_{4}$ and $\mathrm{F}$ were determined by the ionic chromatography. Stable isotopes of oxygen and hydrogen $\left({ }^{18} \mathrm{O}, \mathrm{D}\right)$ and radioactive isotope (tritium) were also determined, though isotope samples were collected from selected wells. The studies of the stable isotopes of oxygen, hydrogen and tritium were carried out in order to determine the similarity of the isotopic composition and, consequently, the recharge conditions and the residence time of these waters in the aquifers. Isotopic analyses were performed by the Hydrogeological Laboratory of the Polish Geological Institute in Warsaw and the Geological Institute of the Polish Academy of Science.

\subsection{Hydrochemical Modelling}

In order to study the processes governing the water chemistry in this area, the authors performed the calculations using $W A T E Q 4 F$ speciation model. The model was based on the data from the field measurements of $\mathrm{pH}$, temperature and $\mathrm{EC}$ and the results of chemical analyses. Principal aqueous species of $\mathrm{Ca}, \mathrm{Mg}, \mathrm{Na}, \mathrm{K}, \mathrm{Fe}, \mathrm{Mn}$ and $\mathrm{Zn}$ were predicted for the waters as well as the saturation indices (SI). The model uses the Davies equation and the extended Debye-Huckel equation to calculate activity coefficients. It solves a set of non-linear mass action and mass balance equations using the continuous fraction iteration. The consistent database which contains the components considered in this study is available within the program.

The verified analytical and field data for every sample site have been input to the hydrogeochemical spatial database (based on the Geomedia software) for permanent storage, retrieval and analysis. For the modelled data spatial distribution and interpolation Golden Software SURFER was used, and the Linear Regression analysis and correlations between anions and cations were performed using STATISTICA.

\section{Results}

\subsection{Division of the Neogene Aquifers}

As a result of detailed geological and hydrogeological studies supported by hydrogeochemical study, as many as 10 aquifers have been distinguished in the Neogene basin (Table 1). They appear as discontinuous and fragmented covers and lenses cut from the surface by a number of erosive gutters of contemporary rivers and fossil valleys. In these gutters there are sandy formations forming the combined Quaternary-Neogene horizons.

The general direction of groundwater flow is from the south-west to north-east (Fig. 3). 


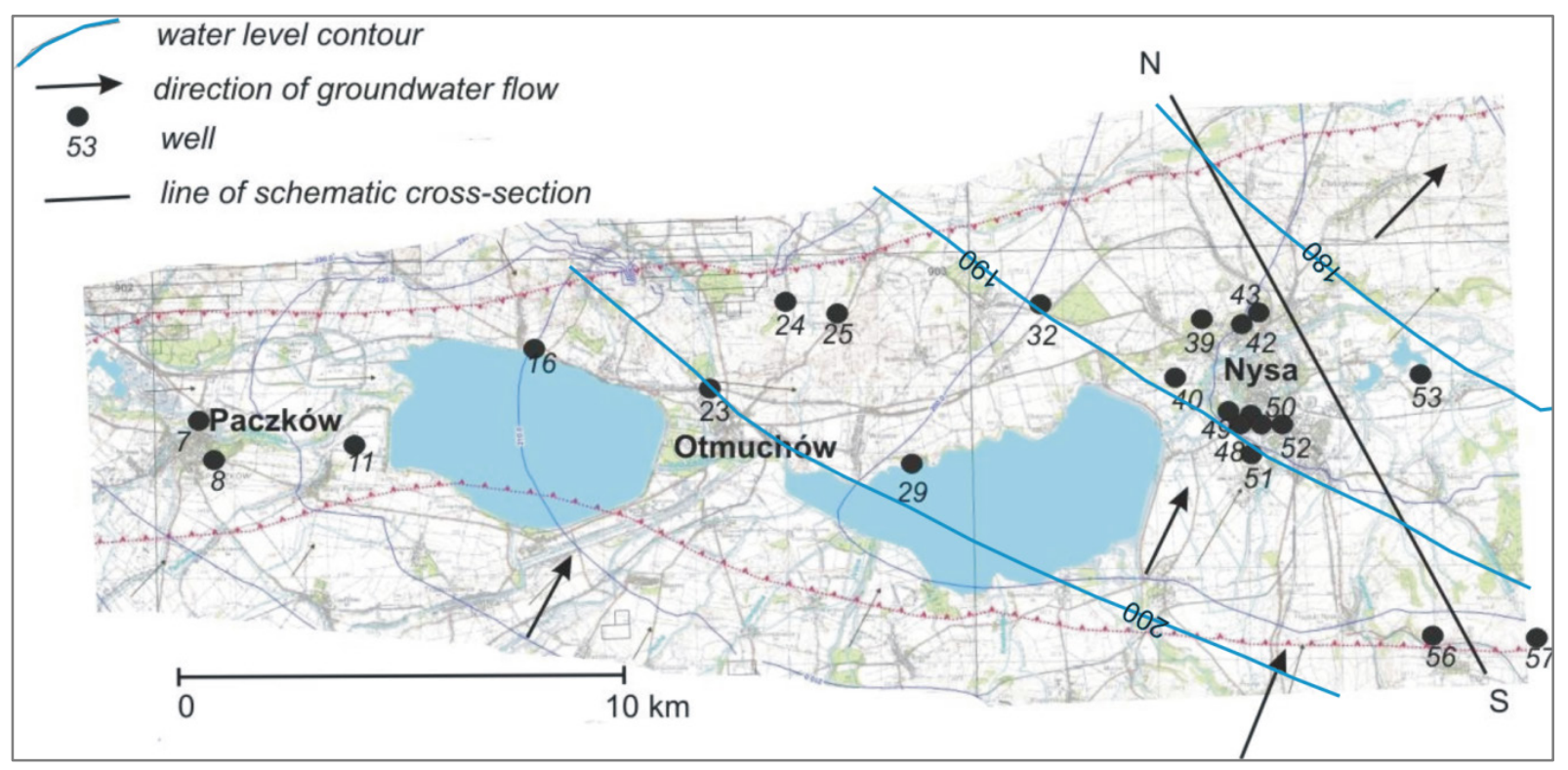

Figure 3. Hydrogeological map of the western part of the Neogene groundwater basin. Water level contours of aquifers no 3, 4.

The water level of all the aquifers in this part of the basin stabilizes a few meters above the surface (flowing wells) [30]. In the Neogene basin the most widespread and productive are four aquifers: $3,4,5$ and 6 (Table. 1) reaching the discharge of $70 \mathrm{~m}^{3} / \mathrm{h}$ with relatively small depressions, but the hydraulic gradients are very small which causes very long travel times, which range from several years in outcrop zones (outside this part of the basin), to thousands of years in the deeper aquifers [33].

The aquifers 1 and 2 belong to the Quaternary and occur mainly in the uplands, and are poorly isolated from the surface. The Neogene aquifers: 3 and 4 occur at the ordinates of 210-140 m above sea level and are the most widely distributed and important for drinking water and are well isolated from the surface. The Neogene aquifers: 5 and 6 lie at the ordinates of $140-90 \mathrm{~m}$ above sea level. They also have a large extent and are exploited. On the basis of the pressure analysis, it can be concluded that there is limited contact between the aquifers 1 and 2 and the underlying layers 3,4 and 5 , which in turn remain hydraulically related to each other. The Neogene aquifers: 7, 8, 9 and 10 lying below $90 \mathrm{~m}$ above sea level and being very well isolated from the surface, have the smallest extent. The Neogene aquifers are recharged in several small zones: mainly in the south-west and south-east of the Nysa town. The greatest hydraulic gradients occur in the southern part, in aquifer 3 , where the greatest falls in the area are related to the southern border of the basin at the slope of the Eastern Sudetes, and the lowest in the northern part of the basin in aquifer 6. These groundwater are modern waters, which were confirmed by examining their age as a result of isotope studies. Only in the Nysa region, at a depth of $180 \mathrm{~m}$ and greater, waters have been defined as pre-Holocene. In the Neogene base pore and fissure-pore waters in the Upper Cretaceous deposits have been observed. The hydrogeological conditions of the Cretaceous aquifer in this region are poorly recognized and the potential discharges are below $10 \mathrm{~m}^{3} / \mathrm{h}$.

In the western part of the Neogene basin 29 wells are situated [33]. Aquifers 3 and 4 have the greatest extent and importance in this region. Aquifers 5 and 6 are also exploited but in a smaller extend. Aquifers: 7, 8, 9 and 10 have a negligible importance due to high fluoride content. Currently, only two wells are active in the aquifer 7 .

\subsection{Hydrochemical Characteristic of Groundwater}

The waters in the individual 10 aquifers in the Neogene basin vary in their physicochemical composition (Table 2), even the chemical types of these waters are different. In shallower aquifers, these are $\mathrm{HCO}_{3}-\mathrm{Ca}-\mathrm{Na}$ or $\mathrm{HCO}_{3}-\mathrm{SO}_{4}-\mathrm{Ca}-\mathrm{Mg}$ waters, in deeper aquifers they are $\mathrm{HCO}_{3}-\mathrm{Na}-\mathrm{Ca}$ and $\mathrm{Cl}-\mathrm{HCO}_{3}-\mathrm{Na}-\mathrm{Ca}$ waters. The major ions were statistically analysed and the results are presented in table 3 . 
Occurrence, Origin and Health Hazards of High Fluoride Waters in the Western Part of the Neogene Sedimentary Basin in Opole Province, Poland

Table 2. Results of physicochemical analyses of waters from wells in the western part of the Neogene basin

\begin{tabular}{|c|c|c|c|c|c|c|c|c|c|c|c|c|c|c|c|}
\hline \multicolumn{2}{|c|}{ No. of well } & 37 & 28 & 1 & 6 & 7 & 11 & 12 & 13 & 34 & 57 & 20 & 21 & 23 & 51 \\
\hline Aquifer & $\mathrm{No}$ & 1 & 2 & 3 & 3 & 3 & 3 & 3 & 3 & 3 & 3 & 4 & 4 & 4 & 4 \\
\hline $\begin{array}{c}\text { Aquifer } \\
\text { depth }\end{array}$ & $\mathrm{m}$ & 16.5 & 23.0 & 50.0 & 23.8 & 52.3 & 50.0 & 57.5 & 66.0 & 46.0 & 110.0 & 66.0 & 67.0 & 63.0 & 34.5 \\
\hline $\begin{array}{c}\text { Water } \\
\text { level }\end{array}$ & $\mathrm{m}$ & 3.3 & $\mathrm{nd}$ & $\mathrm{fw}$ & $\mathrm{nd}$ & $\mathrm{fw}$ & $\mathrm{nd}$ & 17.6 & 10.65 & 24.00 & 96.00 & $\mathrm{nd}$ & $\mathrm{nd}$ & 7.5 & $\mathrm{fw}$ \\
\hline $\mathrm{pH}$ & & 6.8 & 6.5 & - & - & 6.8 & 6.7 & 7.2 & - & 7.4 & 7.8 & 7.2 & 7.0 & - & - \\
\hline $\mathrm{TDS}$ & $\mathrm{mg} / \mathrm{L}$ & 161 & 356 & - & - & 222 & 213 & 512 & - & 394 & 323 & 275 & - & - & - \\
\hline $\mathrm{F}$ & $\mathrm{mg} / \mathrm{L}$ & $<0.10$ & 0.07 & 0.35 & 0.19 & 0.70 & 0.57 & 3.30 & 0.12 & 1.32 & 1.15 & 2.22 & 3.50 & 5.42 & 2.51 \\
\hline $\mathrm{HCO}$ & $\mathrm{mg} / \mathrm{L}$ & - & - & - & - & 138.0 & 116.0 & - & - & 199.0 & 222.0 & 144.0 & - & - & - \\
\hline $\mathrm{SO}_{4}$ & $\mathrm{mg} / \mathrm{L}$ & - & - & - & - & 1.94 & 12.60 & - & - & 62.40 & 3.03 & 8.34 & - & - & - \\
\hline $\mathrm{Cl}$ & $\mathrm{mg} / \mathrm{L}$ & 3 & 42.6 & - & - & 2.26 & 3.74 & 10.6 & - & 14.00 & 2.67 & 21.20 & 48 & - & - \\
\hline $\mathrm{SiO}$ & $\mathrm{mg} / \mathrm{L}$ & - & - & - & - & 51.1 & 42.4 & - & - & 17.6 & 20.3 & 29.8 & - & - & - \\
\hline $\mathrm{Ca}$ & $\mathrm{mg} / \mathrm{L}$ & 18.9 & 45.8 & - & - & 9.2 & 16.9 & 91.5 & - & 84.1 & 42.0 & 16.1 & - & - & - \\
\hline $\mathrm{Mg}$ & $\mathrm{mg} / \mathrm{L}$ & - & - & - & - & 4.70 & 5.30 & - & - & 6.70 & 8.50 & 4.10 & - & - & - \\
\hline $\mathrm{Na}$ & $\mathrm{mg} / \mathrm{L}$ & 6.1 & 18.5 & - & - & 12.4 & 13.3 & 9.4 & - & 7.4 & 21.9 & 47.4 & - & - & - \\
\hline $\mathrm{K}$ & $\mathrm{mg} / \mathrm{L}$ & - & - & - & - & 1.70 & 1.80 & - & - & 1.30 & 1.90 & 2.30 & - & - & - \\
\hline
\end{tabular}

\begin{tabular}{|c|c|c|c|c|c|c|c|c|c|c|c|c|c|c|c|}
\hline \multicolumn{2}{|c|}{ No. of well } & 56 & 61 & 115 & 43 & 47 & 49 & 52 & 48 & 53 & 39 & 40 & 41 & 50 & 42 \\
\hline Aquifer & $\mathrm{No}$. & 4 & 4 & 4 & 5 & 6 & 6 & 6 & 7 & 7 & 8 & 8 & 9 & 9 & 10 \\
\hline $\begin{array}{c}\text { Aquifer } \\
\text { depth }\end{array}$ & $\mathrm{m}$ & 126.0 & 148.3 & & 54.0 & 71.0 & 80.0 & 70.7 & 128.0 & 103.0 & 160.0 & 137.0 & 180.0 & 175.0 & 190.0 \\
\hline $\begin{array}{c}\text { Water } \\
\text { level }\end{array}$ & $\mathrm{m}$ & 25.4 & $\mathrm{nd}$ & $\mathrm{nd}$ & $\mathrm{fw}$ & $\mathrm{fw}$ & $\mathrm{fw}$ & 1.78 & $\mathrm{fw}$ & $\mathrm{fw}$ & $\mathrm{fw}$ & $\mathrm{fw}$ & $\mathrm{fw}$ & 11.20 & $\mathrm{fw}$ \\
\hline $\mathrm{pH}$ & & 5.7 & 7.7 & 7.2 & 7.0 & 7.5 & 7.6 & 7.9 & 7.8 & 6.6 & 7.6 & 7.4 & - & 6.8 & 8.1 \\
\hline $\mathrm{TDS}$ & $\mathrm{mg} / \mathrm{L}$ & 392 & 376 & 412 & - & 342 & 351 & 307 & 371 & 349 & 370 & 401 & - & - & 449 \\
\hline $\mathrm{F}$ & $\mathrm{mg} / \mathrm{L}$ & 1.20 & 1.05 & $<0.10$ & 0.30 & 3.45 & 1.70 & 0.39 & 4.92 & 3.73 & 4.03 & 6.30 & 4.53 & 6.00 & 4.86 \\
\hline $\mathrm{HCO}$ & $\mathrm{mg} / \mathrm{L}$ & 123.0 & 246.0 & 281.0 & - & 132.0 & 234.0 & - & 162.3 & 105.0 & - & - & - & - & 243.0 \\
\hline $\mathrm{SO}{ }_{4}$ & $\mathrm{mg} / \mathrm{L}$ & 80.70 & 8.62 & 12.00 & - & 9.59 & 5.03 & - & 9.75 & 9.25 & - & - & - & - & 1.14 \\
\hline $\mathrm{Cl}$ & $\mathrm{mg} / \mathrm{L}$ & 51.70 & 14.00 & 3.22 & - & 75.40 & 4.59 & 2 & 61.80 & 102.00 & 68 & 42 & - & - & 59.00 \\
\hline $\mathrm{SiO}$ & $\mathrm{mg} / \mathrm{L}$ & 24.0 & 15.7 & 23.4 & - & 26.6 & 22.9 & - & 30.12 & 20.4 & - & - & - & - & 12.5 \\
\hline $\mathrm{Ca}$ & $\mathrm{mg} / \mathrm{L}$ & 70.3 & 43.5 & 67.9 & - & 30.0 & 39.8 & 31.1 & 28.7 & 28.8 & 30.6 & 25.8 & - & - & 25.1 \\
\hline $\mathrm{Mg}$ & $\mathrm{mg} / \mathrm{L}$ & 15.90 & 8.70 & 15.50 & - & 4.30 & 8.20 & - & 4.66 & 3.90 & - & - & - & - & 4.00 \\
\hline $\mathrm{Na}$ & $\mathrm{mg} / \mathrm{L}$ & 18.4 & 35.9 & 7.5 & - & 59.4 & 32.7 & 32.1 & 65.16 & 74.2 & 61.6 & 70.7 & - & - & 97.6 \\
\hline $\mathrm{K}$ & $\mathrm{mg} / \mathrm{L}$ & 6.60 & 2.30 & 1.30 & - & 1.40 & 2.00 & - & 1.55 & 1.30 & - & - & - & - & 1.60 \\
\hline
\end{tabular}

fw - flowing well,

nd - no data

Based on the physicochemical analyses, the water of this Neogene basin can be classified as freshwater, with total dissolved solids ranging from $102 \mathrm{mg} / \mathrm{L}$ to $450 \mathrm{mg} / \mathrm{L}$, with an average of $302.7 \mathrm{mg} / \mathrm{L}$ [33]. The values of electrolytic conductivity reach the maximum of $619 \mu \mathrm{S} / \mathrm{cm}$ in aquifer 4 , and $598 \mu \mathrm{S} / \mathrm{cm}$ in aquifer 10 . There is a clear downward trend in the electrolytic conductivity towards the north-east and west, and high values are in the Nysa region. Higher values in the south are related to the influence of Palaeozoic-Precambrian deposits, while lower values in the west are related to the shallower position of the aquifers. The $\mathrm{pH}$ value ranges from 5.7 to 8.0 , in most cases, these are slightly alkaline and alkaline waters. The temperature of groundwater ranges from 11.7 to $14.4^{\circ} \mathrm{C}$ and is determined by the depth of the aquifers. In figure 4 , the chemical composition of groundwater in the whole Neogene basin is presented. The fluoride content in the whole basin ranges from below 0.05 to $6.30 \mathrm{mg} / \mathrm{L}$, with a median of $0.37 \mathrm{mg} / \mathrm{L}$ and an average of $1.33 \mathrm{mg} / \mathrm{l}$. 
Table 3. Major cations, anions, TDS and $\mathrm{pH}$ of waters in aquifers in the Neogene basin

\begin{tabular}{|c|c|c|c|c|c|c|c|c|c|c|c|}
\hline \multirow{2}{*}{ Parameter } & \multirow{2}{*}{$\mathrm{pH}$} & TDS & $\mathrm{F}$ & $\mathrm{HCO}_{3}^{-}$ & $\mathrm{SO}_{4}$ & $\mathrm{Cl}$ & $\mathrm{SiO}_{2}$ & $\mathrm{Ca}$ & $\mathrm{Mg}$ & $\mathrm{Na}$ & $\mathrm{K}$ \\
\hline & & \multicolumn{10}{|c|}{$m g / L$} \\
\hline \multicolumn{12}{|c|}{ Aquifer 3} \\
\hline Average & 7.2 & 333 & 0.96 & 168.8 & 20.0 & 6.7 & 32.9 & 48.7 & 6.3 & 12.9 & 1.7 \\
\hline Median & 7.2 & 323 & 0.64 & 168.5 & 7.8 & 3.7 & 31.4 & 42.0 & 6.0 & 12.4 & 1.8 \\
\hline Minimum & 6.6 & 213 & 0.12 & 116 & 1.94 & 2.26 & 17.6 & 9.2 & 4.7 & 7.4 & 1.3 \\
\hline Maximum & 7.8 & 512 & 3.30 & 222 & 62.4 & 14 & 51.1 & 91.5 & 8.5 & 21.9 & 1.9 \\
\hline \multicolumn{12}{|c|}{ Aquifer 4} \\
\hline Average & 6.9 & 364 & 2.65 & 198.5 & 27.4 & 27.6 & 23.2 & 49.5 & 11.1 & 27.3 & 3.1 \\
\hline Median & 7.2 & 384 & 2.37 & 195.0 & 10.3 & 21.2 & 23.7 & 55.7 & 12.1 & 27.2 & 2.3 \\
\hline Minimum & 5.7 & 276 & 1.05 & 123.0 & 8.3 & 3.2 & 15.7 & 16.1 & 4.1 & 7.5 & 1.3 \\
\hline Maximum & 7.7 & 412 & 5.42 & 281.0 & 80.7 & 51.7 & 29.8 & 70.3 & 15.9 & 47.4 & 6.6 \\
\hline \multicolumn{12}{|c|}{ Aquifers 5, 6} \\
\hline Average & 7.7 & 333 & 1.46 & 183.0 & 7.3 & 27.3 & 24.8 & 33.6 & 6.3 & 41.4 & 1.7 \\
\hline Median & 7.6 & 342 & 1.05 & 183.0 & 7.3 & 4.6 & 24.8 & 31.1 & 6.3 & 32.7 & 1.7 \\
\hline Minimum & 7.5 & 307 & 0.39 & 132.0 & 5.0 & 2.0 & 22.9 & 30.0 & 4.3 & 32.1 & 1.4 \\
\hline Maximum & 7.9 & 351 & 3.45 & 234.0 & 9.6 & 75.4 & 26.6 & 39.8 & 8.2 & 59.4 & 2.0 \\
\hline \multicolumn{12}{|c|}{ Aquifers 7, 8, 9} \\
\hline Average & 7.3 & 372.5 & 4.75 & 133.7 & 9.5 & 68.5 & 25.3 & 28.5 & 4.28 & 67.9 & 1.43 \\
\hline Median & 7.5 & 370.5 & 4.48 & 133.7 & 9.5 & 64.9 & 25.3 & 28.8 & 4.28 & 67.9 & 1.43 \\
\hline Minimum & 6.6 & 348.0 & 3.73 & 105.0 & 9.3 & 42.0 & 20.4 & 25.8 & 3.90 & 61.6 & 1.30 \\
\hline Maximum & 7.8 & 401.0 & 6.30 & 162.3 & 9.8 & 102.0 & 30.1 & 30.6 & 4.66 & 74.2 & 1.55 \\
\hline \multicolumn{12}{|c|}{ Aquifer 10} \\
\hline Well 42 & 8.1 & 449 & 4.86 & 243.0 & 1.14 & 59.0 & 12.5 & 25.1 & 4.00 & 97.6 & 1.60 \\
\hline \multicolumn{12}{|c|}{ Whole fluoride anomaly $(\mathrm{n}=29)$} \\
\hline Average & 7.2 & 346 & 2.23 & 180.4 & 17.26 & 31.6 & 25.9 & 39.3 & 7.27 & 36.4 & 2.1 \\
\hline Median & 7.2 & 356 & 1.51 & 162.3 & 9.25 & 17.6 & 23.4 & 30.6 & 5.3 & 32.1 & 1.7 \\
\hline Minimum & 5.7 & 161 & 0.05 & 105 & 1.14 & 2 & 12.5 & 9.2 & 3.9 & 6.1 & 1.3 \\
\hline Maximum & 8.1 & 512 & 6.3 & 281 & 80.7 & 102 & 51.1 & 91.5 & 15.9 & 97.6 & $\overline{6.6}$ \\
\hline $\begin{array}{c}\text { Std } \\
\text { deviation }\end{array}$ & 0.56 & 83.83 & 1.954 & 59.31 & 24.65 & 30.5 & 10.7 & 23.3 & 4.13 & 27.7 & 1.4 \\
\hline
\end{tabular}

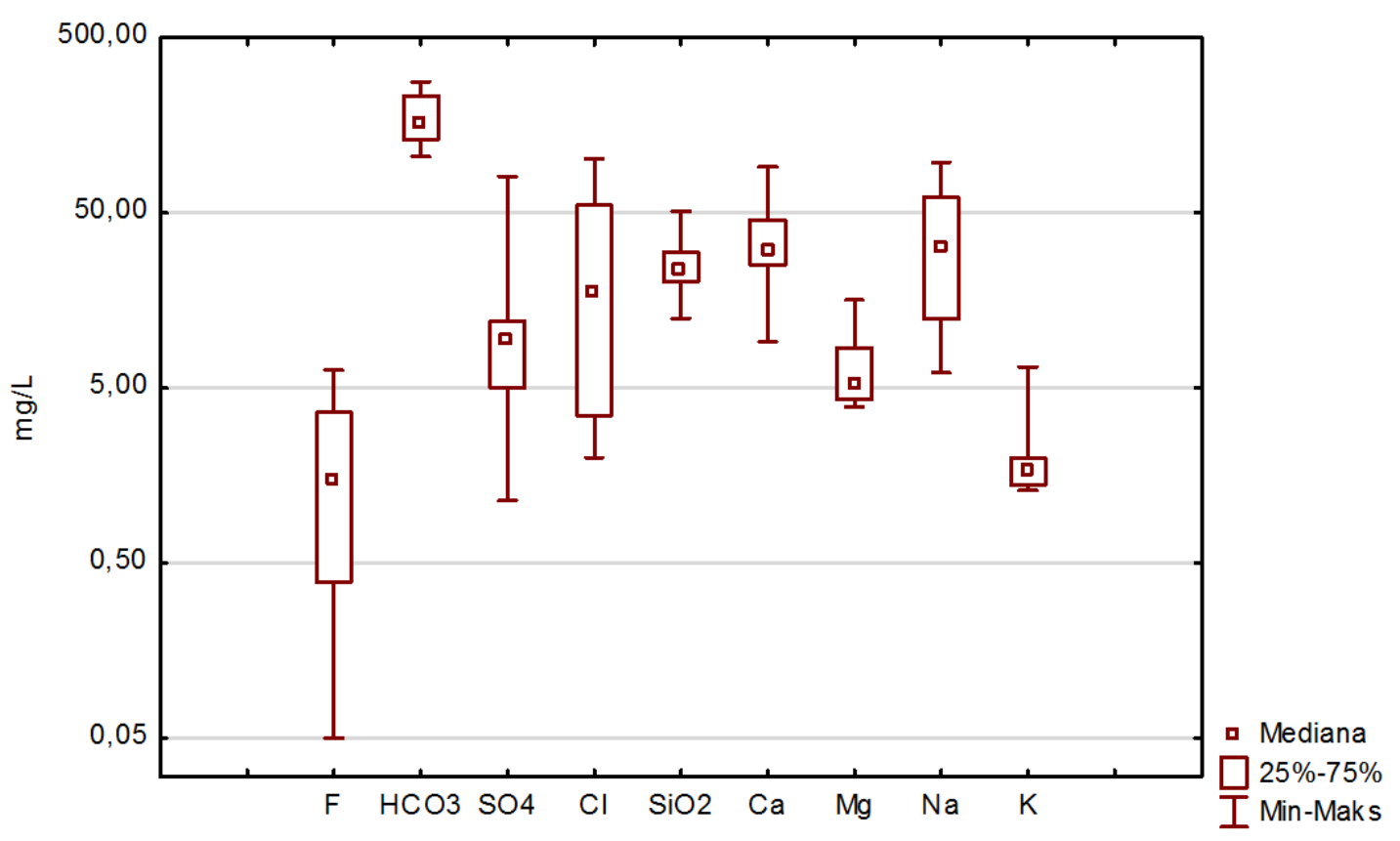

Figure 4. Box plot of the major cations and anions in groundwater in the Neogene basin 


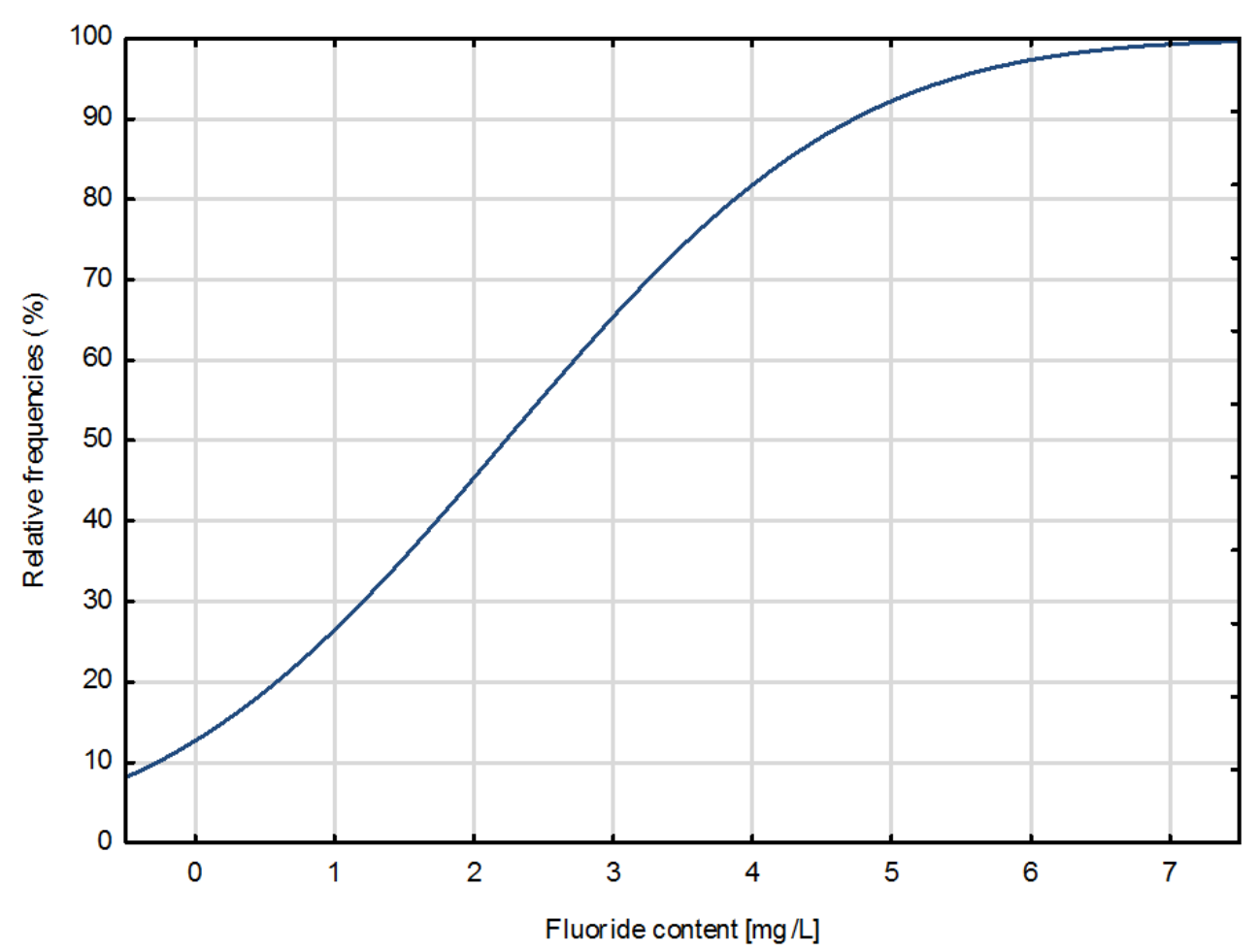

Figure 5. Relative frequency plot of fluoride content in groundwater in the western part of the Neogene basin

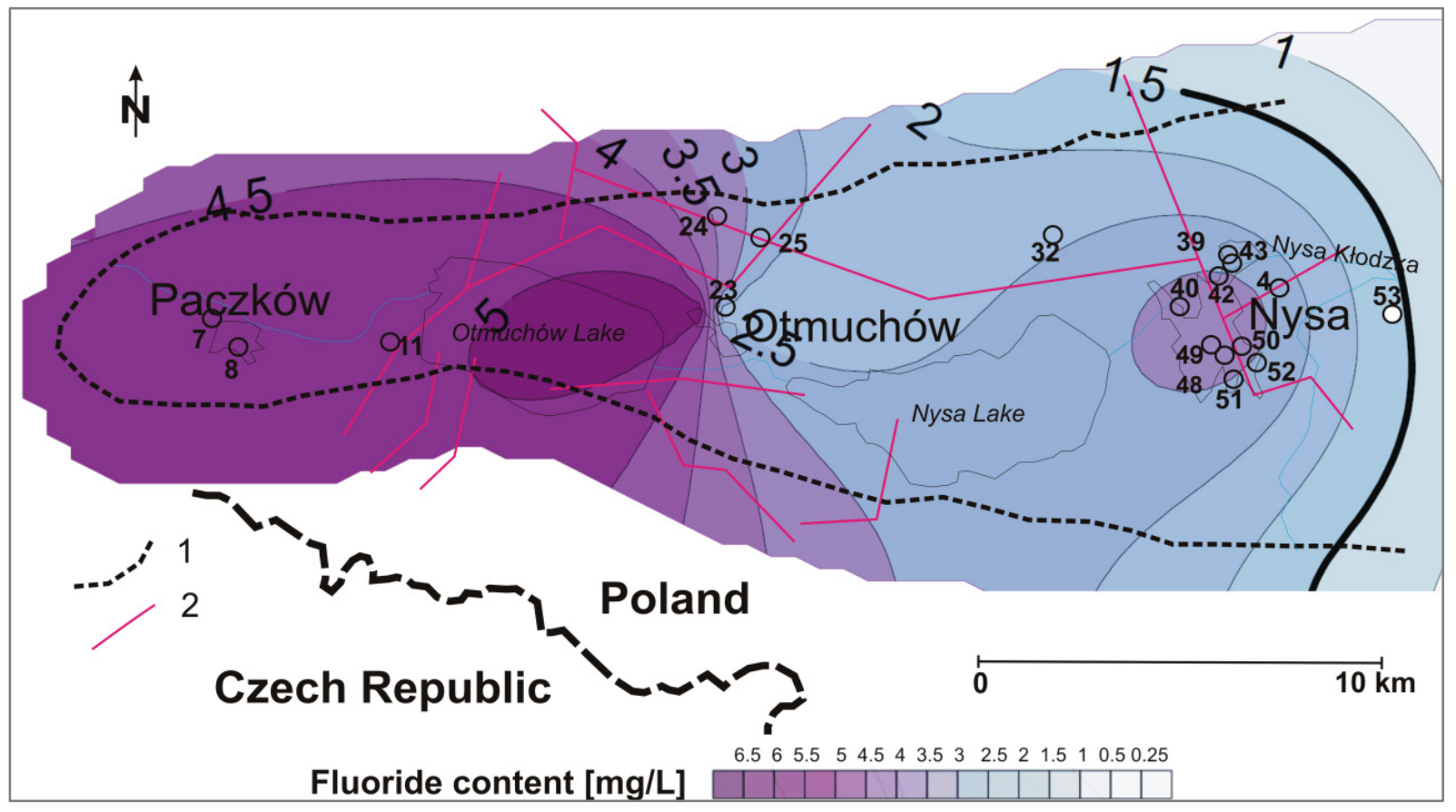

1 -Neogene basin border, 2 - main faults

Figure 6. Fluoride content in groundwater in the aquifer 4 in the western part of the Neogene basin 


\subsection{Fluoride Anomaly}

The biggest concern within the studied Neogene basin is the contamination of groundwater with fluoride, the content of which is very high and amounts to a maximum of $6.3 \mathrm{mg} / \mathrm{L}$ [31] but a single result of $11.5 \mathrm{mg} / \mathrm{L}$ was documented by Koślacz [20]. Fluoride content exceeds many times the limit values for waters for human consumption, what is $1.5 \mathrm{mg} / \mathrm{L}$ [42]. The highest content of fluoride has been observed in the western part of the basin, where in $60 \%$ of the analyses fluoride content exceeds 1.5 (Fig. 5). The average content of fluoride in this part of the basin is $2.23 \mathrm{mg} / \mathrm{L}$, and the median is $1.51 \mathrm{mg} / \mathrm{L}$ (Table 3). Median value is four times higher here than in the rest of the basin. High concentrations of fluoride are already present in the aquifer 3, where in the wells in Otmuchów area (Table 2) they exceed $1.5 \mathrm{mg} / \mathrm{L}$. In the aquifer 4 , in the zone between Nysa and Paczków (Fig. 6), the concentration of fluoride is very varied and ranges from 1.5 $\mathrm{mg} / \mathrm{L}$ to $5.4 \mathrm{mg} / \mathrm{L}$ with the median of $2.37 \mathrm{mg} / \mathrm{L}$.

The changes of fluoride content in aquifer 4 do not depend on the direction of groundwater flow, but the concentrations are higher in the area with numerous faults (Fig. 6).

The highest concentrations of fluoride occur in aquifers 7, 8, 9 and 10 in the Nysa region and to the west of Nysa and range from $3 \mathrm{mg} / \mathrm{L}$ to $6.3 \mathrm{mg} / \mathrm{L}$ with the median of 4.5 $\mathrm{mg} / \mathrm{L}$ (Fig. 7). On the other hand, in aquifers 5 and 6 , fluoride concentrations are lower probably due to the presence of calcareous and marly interlayers, which cause the precipitation of calcium fluoride, contributing to the reduction of fluoride concentrations in these waters (median is $1.05 \mathrm{mg} / \mathrm{L}$ ). High concentrations of fluoride probably occur within aquifers: 7, 8, 9 and 10 throughout the entire area of the basin, but in the eastern part they have not been documented due to the lack of wells.

Fluoride content is highest at great depths, but there is no clear trend of increasing with depth. Fluoride concentrations above $1.0 \mathrm{mg} / \mathrm{L}$ are already present in the shallow aquifers, but also low concentrations $(0.14 \mathrm{mg} / \mathrm{L})$ at depths below $100 \mathrm{~m}$ were noticed in this basin.

The concentrations of major ions in waters of the Neogene basin within the largest fluoride anomaly (aquifers 4 and 7,8,9,10) are higher than in the rest of the area (Fig. 8).

The TDS values are in the range from $276 \mathrm{mg} / \mathrm{L}$ to 449 $\mathrm{mg} / \mathrm{L}$ (Table 2). The $\mathrm{pH}$ value ranges from 5.7 to 8.1 , with an average of 7.8, these waters can be described as slightly alkaline and alkaline. In the figure 8 the differences of chemical composition between the individual Neogene aquifers are shown.

Bicarbonate ion $\left(\mathrm{HCO}_{3}^{-}\right)$originates from rocks containing fluorite and calcite. Its concentration ranges from 105.0 to $281.0 \mathrm{mg} / \mathrm{L}$. The average and median values are similar in each aquifer, but different minerals are the main sources of bicarbonate in aquifer 3 and the others in aquifers 4 or $7,8,9,10$.

Chloride ion $\left(\mathrm{Cl}^{-}\right)$content increases with a depth and the highest are in aquifers 7,8,9, where ranges from 42 to 102 $\mathrm{mg} / \mathrm{L}$ (median 64,9 mg/L). Chloride ions show close correlation with $\mathrm{F}, \mathrm{Na}, \mathrm{Ca}$ and $\mathrm{Br}$ ions (Table 4).

Sulphate ion $\left(\mathrm{SO}_{4}{ }^{2-}\right)$ concentrations are not high and reach a maximum of $80.7 \mathrm{mg} / \mathrm{L}$ in the aquifer 4 , in aquifers 5-10 are very low with median values around 7.3 - 9.5 $\mathrm{mg} / \mathrm{L}$ (Table 2). As the $\mathrm{pH}$ increases, the sulphate content of water decreases.

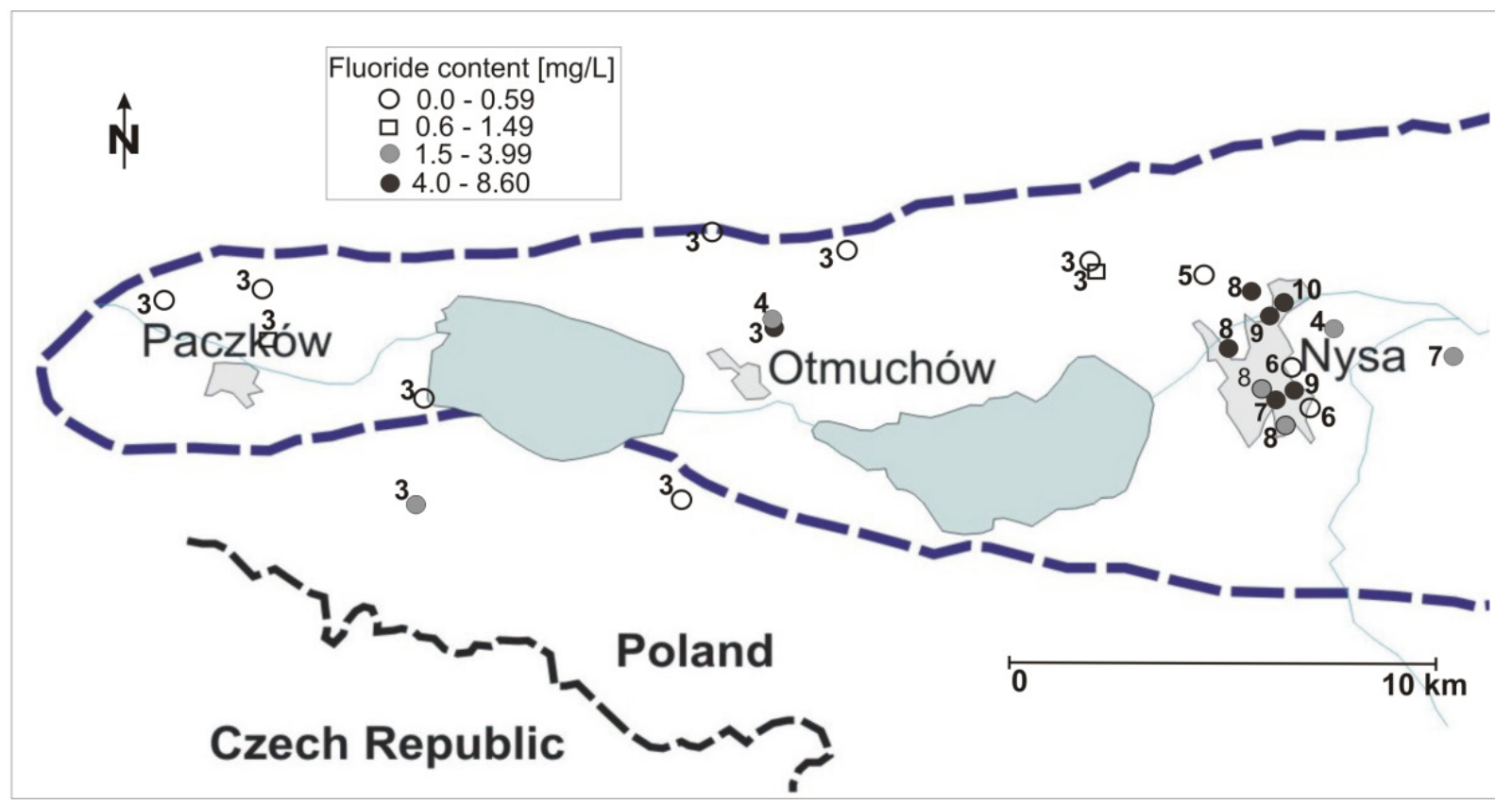

Figure 7. Fluoride content in groundwater in the aquifers 3-10 in the western part of the Neogene basin. Numbers depict the Neogene aquifers 


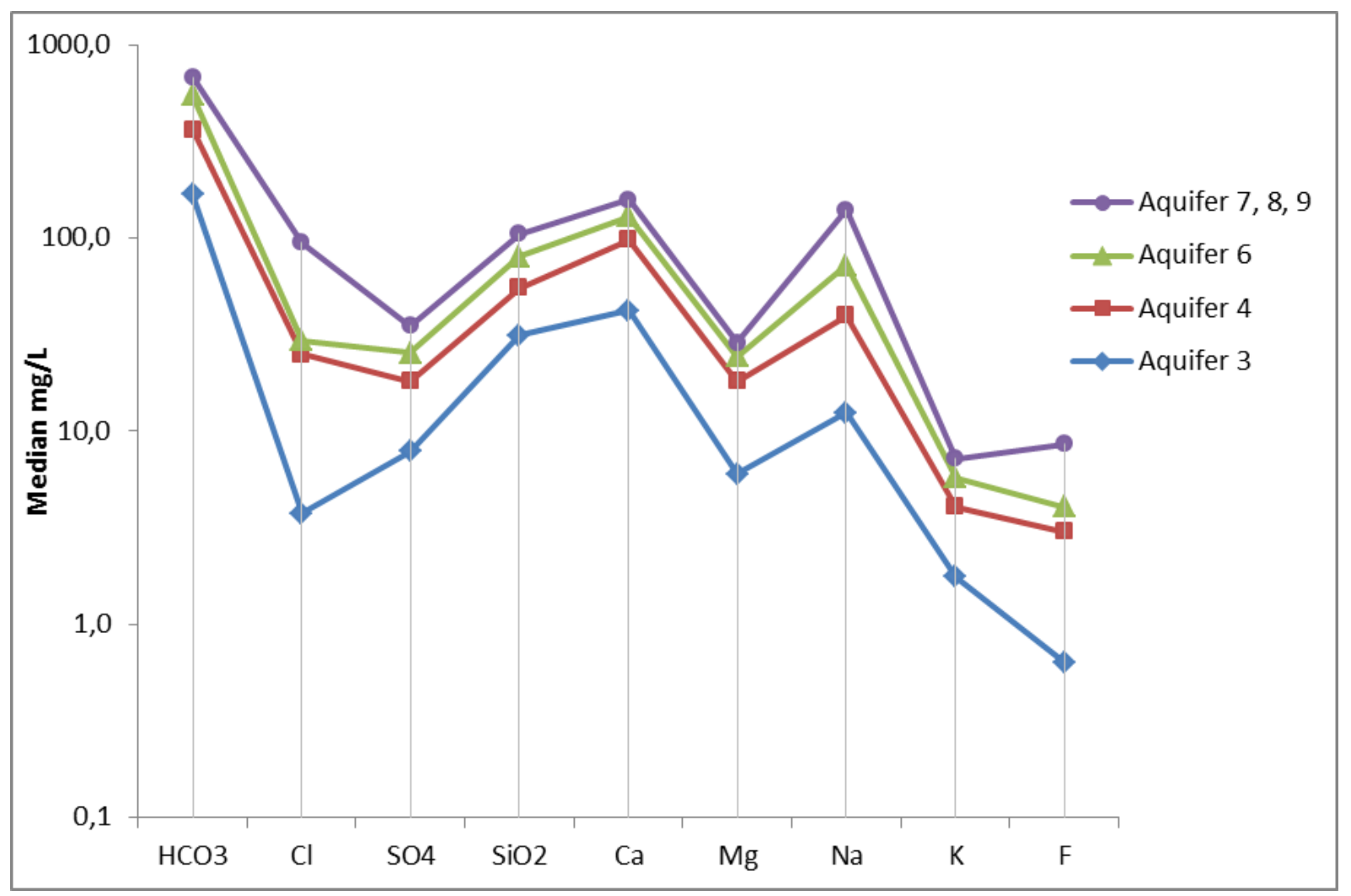

Figure 8. Schoeller plot of median values of major cations and anions in the western part of the Neogene basin

Table 4. Correlation coefficient of the major parameters in the Neogene aquifer (highlighted font indicates significant correlation)

\begin{tabular}{|c|c|c|c|c|c|c|c|c|c|c|}
\hline Parameter & $\mathbf{F}$ & $\mathbf{p H}$ & $\mathbf{T D S}$ & $\mathbf{H C O}_{3}$ & $\mathbf{C l}$ & $\mathbf{C a}$ & $\mathbf{N a}$ & $\mathbf{K}$ & $\mathbf{B r}$ & $\mathbf{L i}$ \\
\hline $\mathrm{F}$ & 1.00 & 0.78 & 0.92 & 0.53 & 0.94 & 0.88 & 0.94 & -0.10 & 0.96 & 0.81 \\
\hline $\mathrm{pH}$ & 0.78 & 1.00 & 0.81 & 0.64 & 0.71 & 0.64 & 0.79 & 0.00 & 0.67 & 0.40 \\
\hline $\mathrm{TDS}$ & 0.92 & 0.81 & 1.00 & 0.77 & 0.83 & 0.80 & 0.99 & 0.21 & 0.84 & 0.61 \\
\hline $\mathrm{HCO}_{3}^{-}$ & 0.53 & 0.64 & 0.77 & 1.00 & 0.31 & 0.28 & 0.67 & 0.55 & 0.35 & 0.00 \\
\hline $\mathrm{Cl}$ & 0.94 & 0.71 & 0.83 & 0.31 & 1.00 & 0.93 & 0.90 & -0.24 & 0.98 & 0.88 \\
\hline $\mathrm{Ca}$ & 0.88 & 0.64 & 0.80 & 0.28 & 0.93 & 1.00 & 0.85 & -0.15 & 0.90 & 0.89 \\
\hline $\mathrm{Na}$ & 0.94 & 0.79 & 0.99 & 0.67 & 0.90 & 0.85 & 1.00 & 0.15 & 0.89 & 0.71 \\
\hline $\mathrm{K}$ & -0.10 & 0.00 & 0.21 & 0.55 & -0.24 & -0.15 & 0.15 & 1.00 & -0.28 & -0.26 \\
\hline $\mathrm{Br}$ & 0.96 & 0.67 & 0.84 & 0.35 & 0.98 & 0.90 & 0.89 & -0.28 & 1.00 & 0.87 \\
\hline $\mathrm{Li}$ & 0.81 & 0.40 & 0.61 & 0.00 & 0.88 & 0.89 & 0.71 & -0.26 & 0.87 & 1.00 \\
\hline
\end{tabular}

Calcium ion $\left(\mathrm{Ca}^{2+}\right)$ levels are low $(16.1-70.3 \mathrm{mg} / \mathrm{L})$ with a median $28.8-55.7 \mathrm{mg} / \mathrm{L}$. The situation is similar in the case of magnesium ion $\left(\mathrm{Mg}^{2+}\right)$, which coexists with calcium ion. It reaches a maximum of $15.9 \mathrm{mg} / \mathrm{L}$ in aquifer 4 and a median value ranges from 4.28 to $12.1 \mathrm{mg} / \mathrm{L}$. Calcium shows significant correlations with $\mathrm{Cl}, \mathrm{Br}$ and $\mathrm{Li}$, but not significant correlations with $\mathrm{HCO}_{3}{ }^{-}$(Table 4).
The highest content of sodium ion $\left(\mathrm{Na}^{+}\right)$is in the aquifer 10 , where it reaches the value of $97.6 \mathrm{mg} / \mathrm{L}$. Elevated concentrations are caused by leaching of sodium-rich minerals and ion exchange processes due to long residence time in the aquifer. Sodium content is varied from median $27.2 \mathrm{mg} / \mathrm{L}$ in the aquifer 4 to median $67.9 \mathrm{mg} / \mathrm{L}$ in the aquifers 7-9. 


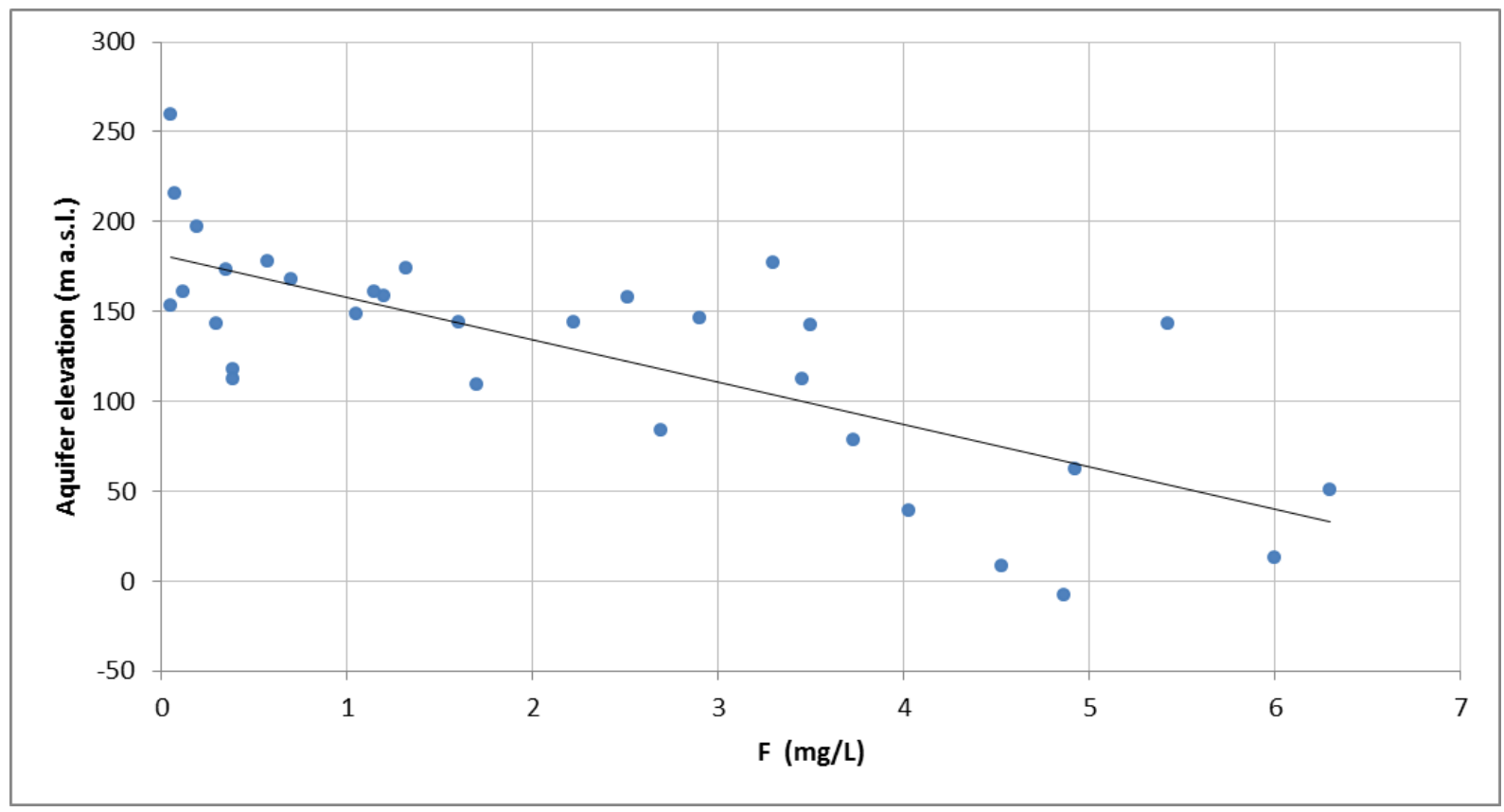

Figure 9. Fluoride content versus elevation of aquifers in the Neogene basin

The study confirmed the upward trend of the fluoride content with the decreasing elevation of the aquifers in the whole Neogene basin (Fig. 9). This is related to the inflow of infiltration waters, poor in fluoride. The highest concentrations are found in waters at elevations of $30-80 \mathrm{~m}$ asl and a depth of $130-165 \mathrm{~m}$ below the surface (aquifers 8 , 9), with the median of $4.48 \mathrm{mg} / \mathrm{L}$ and a maximum of 6.3 $\mathrm{mg} / \mathrm{L}$ [20]. At elevations 90-140 m asl fluoride contents are lower (median $1.05 \mathrm{mg} / \mathrm{L}$ ), which may be caused by the presence of carbonate rocks in the aquifers 5 and 6 [32]. Fluoride has a strong correlation with the sodium (0.94). This is probably related to the circulation of groundwater within the Neogene groundwater basin. The fluoride also shows a strong corelation between $\mathrm{Ca}, \mathrm{Br}$ and $\mathrm{Cl}$ (Table 4). In the studied waters, the fluoride content depends on the TDS of these waters (the correlation coefficient is 0.92) (Table 4).

The spatial distribution of the fluoride content is presented in figures 6 and 7. The highest concentrations of fluoride $(>3 \mathrm{mg} / \mathrm{L})$ occur in the area of Nysa town. The zone of high concentrations continues in the west direction, near Otmuchow. In the area north of Nysa, along a significant fault zone fluoride anomaly also was detected, but it is weaker than in the area of Nysa, the fluoride content in these waters is $0.6-2.7 \mathrm{mg} / \mathrm{L}$. In the rest of the Neogene basin, fluoride contents are lower (less than 0.5 $\mathrm{mg} / \mathrm{L}$ ) [33].

\subsection{Dominant Fluorine Species and Saturation Indices}

Using the WATEQ4F program, an analysis of ion species and saturation indices has also been carried out. The dominant species of total dissolved fluorine in waters in all the aquifers is $\mathrm{F}^{-}$(median $98.5 \%$ ) regardless the fluoride content, while the differences are visible in the number of forms in which it occurs. In the aquifer 3, it occurs as $\mathrm{F}^{-}$in over $98 \%$ of its total concentration, and in a very small percentage as $\mathrm{MgF}$ (Table 5), similarly in the aquifer 4. However, in aquifer 7, despite the great dominance of the $\mathrm{F}^{-}$form, it occurs in a larger number of forms ( $\mathrm{CaF}, \mathrm{MgF}, \mathrm{NaF}, \mathrm{MnF}$ and $\mathrm{ZnF})$.

Using the WATEQ4F program, an analysis of saturation indices (SI) in relation to these mineral phases that significantly affect the chemical composition of groundwater was also performed (Table 5). All the samples were undersaturated with respect to gypsum, dolomite and anhydrite, indicating the dissolution of these minerals. Groundwater samples with low fluoride content were supersaturated relative to quartz. The saturation index of fluorite raises with the increase of fluoride concentrations, and when $\mathrm{F}$ content is above $3 \mathrm{mg} / \mathrm{L}$, it reaches the equilibrium. This is because of the role played by fluorite solubility as a geochemical barrier for fluoride concentrations in most environments [3]. Gypsum shows a dissolution trend in all water samples $(\mathrm{SI}<0)$, as well as the calcite in most samples. SI of calcite doesn't depend either on elevation of the aquifer nor the depth, at high elevations where fluoride content is low, it shows a dissolution trend. 
Table 5. Median of speciations and saturation indices in waters in aquifers in the Neogene basin

\begin{tabular}{|c|c|c|c|c|c|c|c|c|c|c|c|c|}
\hline \multirow{2}{*}{$\begin{array}{c}\text { Aquifer } \\
\text { No. }\end{array}$} & \multicolumn{4}{|c|}{ Fluorine Speciation } & \multicolumn{6}{c|}{ Saturation Index (SI) } \\
\cline { 2 - 6 } & $\mathbf{C a}$ & $\mathbf{M g F}$ & $\mathbf{N a F}$ & $\mathbf{M n F}$ & $\mathbf{Z n F}$ & Fluori-te & Calcite & $\begin{array}{c}\text { Chalce- } \\
\text { dony }\end{array}$ & Gypsum & Dolo-mite & Qartz \\
\hline 3 & 0.03 & 98.29 & 0.20 & 0.00 & 0.02 & 0.03 & -1.40 & -0.78 & 0.36 & -3.07 & -3.45 & 0.82 \\
\hline 4 & 0.03 & 98.06 & 0.21 & 0.01 & 0.02 & 0.04 & -0.74 & -1.01 & 0.27 & -2.78 & -2.40 & 0.74 \\
\hline 6 & 0.07 & 98.47 & 0.52 & 0.01 & 0.05 & 0.10 & -0.36 & -0.26 & 0.29 & -2.95 & -1.08 & 0.75 \\
\hline $7-10$ & 0.12 & 98.78 & 0.95 & 0.01 & 0.09 & 0.10 & 0.09 & -0.15 & 0.20 & -2.90 & -0.88 & 0.66 \\
\hline
\end{tabular}

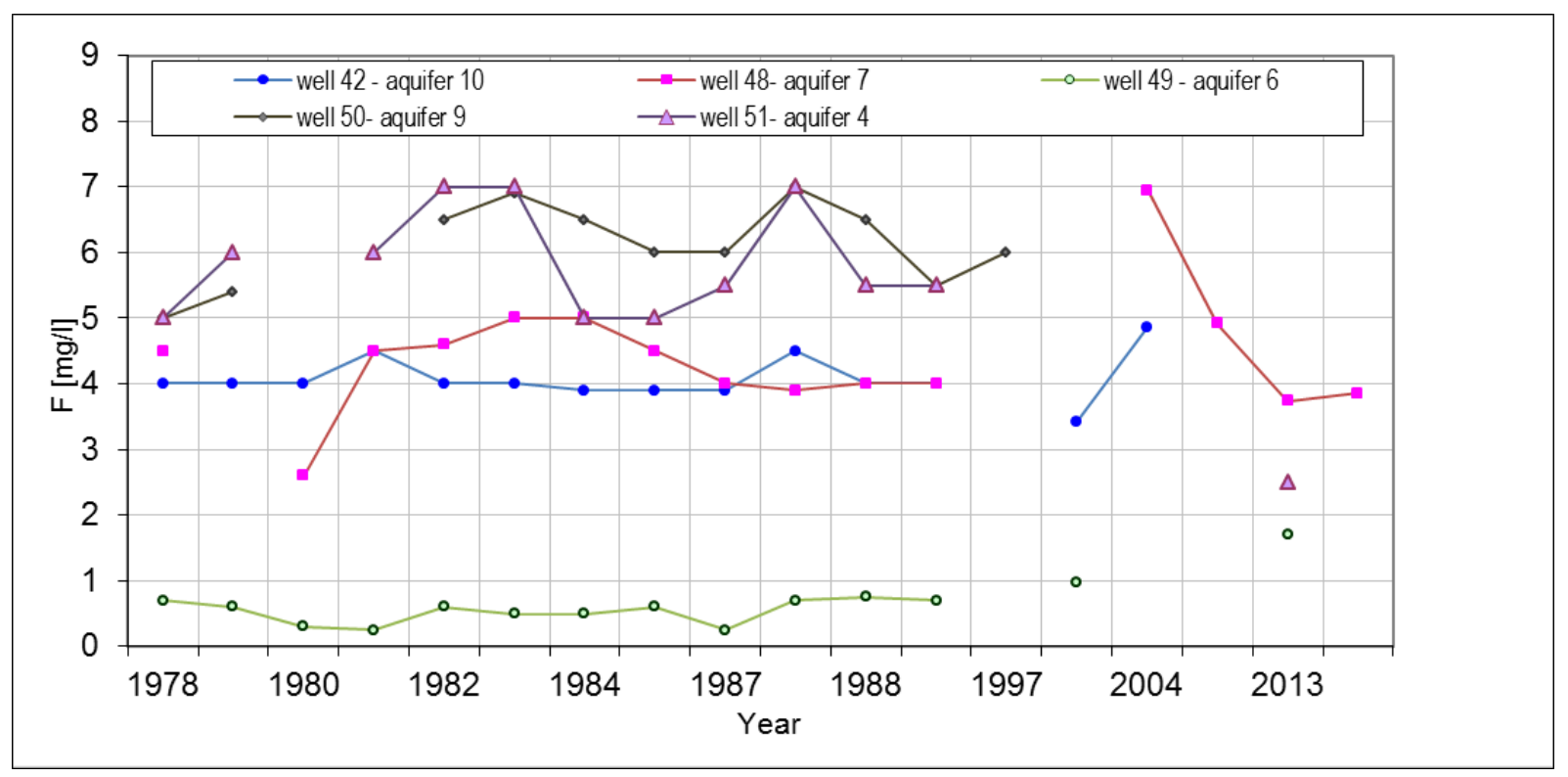

Figure 10. Fluoride concentrations in selected Neogene wells of Nysa Water Works (after Koślacz [20]; modified)

Table 6. Stable isotopes and tritium content in the selected wells in the Neogene aquifers

\begin{tabular}{|c|c|c|c|c|c|c|}
\hline \multirow{2}{*}{$\begin{array}{l}\text { Well } \\
\text { No. }\end{array}$} & \multirow{2}{*}{ Date } & \multirow{2}{*}{$\begin{array}{c}\text { Aquifer } \\
\text { No. }\end{array}$} & Tritium & $\delta^{2} \mathbf{H}$ & $\delta^{18} \mathrm{O}$ & Fluoride \\
\hline & & & T.U. & $\%$ & $\%$ & $\mathrm{mg} / \mathrm{L}$ \\
\hline 11 & $05 / 07 / 2012$ & 3 & 0.21 & -66.70 & -9.26 & 0.57 \\
\hline 7 & 05/07/2012 & 3 & 0.24 & -66.40 & -9.52 & 0.70 \\
\hline 57 & 03/07/2012 & 3 & 0.93 & -72.70 & -10.22 & 1.15 \\
\hline 56 & 05/07/2012 & 4 & 0.88 & -72.50 & -10.24 & 1.20 \\
\hline 197 & $29 / 06 / 2012$ & 4 & 0.26 & -70.02 & -9.82 & 0.12 \\
\hline 83 & $29 / 08 / 2012$ & 5 & 0.20 & -69.10 & -9.52 & 0.21 \\
\hline 94 & $29 / 08 / 2012$ & 5 & 0.09 & -68.50 & -9.61 & 0.32 \\
\hline 131 & $30 / 08 / 2012$ & 6 & 0.25 & -67.70 & -9.45 & 0.18 \\
\hline 53 & $05 / 07 / 2012$ & 7 & 0.73 & -73.80 & -10.42 & 3.73 \\
\hline 42 & $03 / 07 / 2012$ & 10 & 0.00 & -71.00 & -10.02 & 4.86 \\
\hline
\end{tabular}

\subsection{Time Variability of Fluoride Content}

Due to the very long water residence time of these waters, the fluoride contents show stability. This is confirmed by observations of changes of fluoride content over time in the years 1978-2019 (Fig. 10). Some fluctuations of their concentration can be observed here, but the amplitudes are relatively small, hence they do not have a significant impact on trends in changes in the chemical composition of these waters.

\subsection{Stable Isotopes and Tritium Content}

The content of stable oxygen, hydrogen and tritium 
isotopes in waters of the Neogene aquifers has also been analysed (Table 6). The main purpose of this analysis was to assess the water residence time and recharge conditions for individual aquifers and, as a consequence, their possible hydraulic connectivity.

Piezometric pressures in individual aquifers of the Neogene groundwater basin are varied, these differences can be up to several metres. Differences can also be observed in the chemical composition of waters from these aquifers. This may indicate different recharge areas for individual aquifers, but also vertical recharge through clay layers cannot be excluded. The lowest content of stable oxygen and hydrogen isotopes are in the Nysa area and southeast of the town. Water from wells 41, 42, 53, 56 and 57 infiltrated during the interglacial periods which confirms a long residence times of these waters allowing enrichment in fluoride (Table 6), and low tritium content indicates the absence of recent waters. Samples with the lowest content of fluoride (below $1.0 \mathrm{mg} / \mathrm{L}$ ) have the highest content of stable oxygen, which may indicate mixing of these groundwater with modern groundwater (Fig 11).

\section{Discussion}

\subsection{Origin of High Fluoride Waters in the Neogene Aquifers}

The presence of fluoride in groundwater is possible only due to favourable physicochemical conditions and with a long water residence time in the aquifer. In the studied waters, a strong correlation between the aquifer level ordinate and the fluoride content has been observed. The highest levels of fluoride occur in aquifers 7-9, i.e. at ordinates of $30-90 \mathrm{~m}$ a.s.1. The relationship between fluoride content and water type has been observed. For low fluoride content $(<0.15 \mathrm{mg} / \mathrm{L})$ water type is $\mathrm{HCO}_{3}-\mathrm{Ca}-\mathrm{Mg}$ or $\mathrm{HCO}_{3}-\mathrm{SO}_{4}-\mathrm{Ca}$, for medium fluoride content $(0.15$ to 1.5 $\mathrm{mg} / \mathrm{L}$ ) it is $\mathrm{HCO}_{3}-\mathrm{Ca}-\mathrm{Na}$ or $\mathrm{HCO}_{3}-\mathrm{Na}-\mathrm{Ca}$, for higher $\mathrm{F}$ content $(1.5-6.5 \mathrm{mg} / \mathrm{L})$ it is $\mathrm{HCO}_{3}-\mathrm{Cl}-\mathrm{Na}-\mathrm{Ca}$ and for very high $\mathrm{F}$ content $(>6.5 \mathrm{mg} / \mathrm{L})$ the type $\mathrm{Cl}-\mathrm{HCO}_{3}-\mathrm{Na}-\mathrm{Ca}$ prevails (Fig. 12).

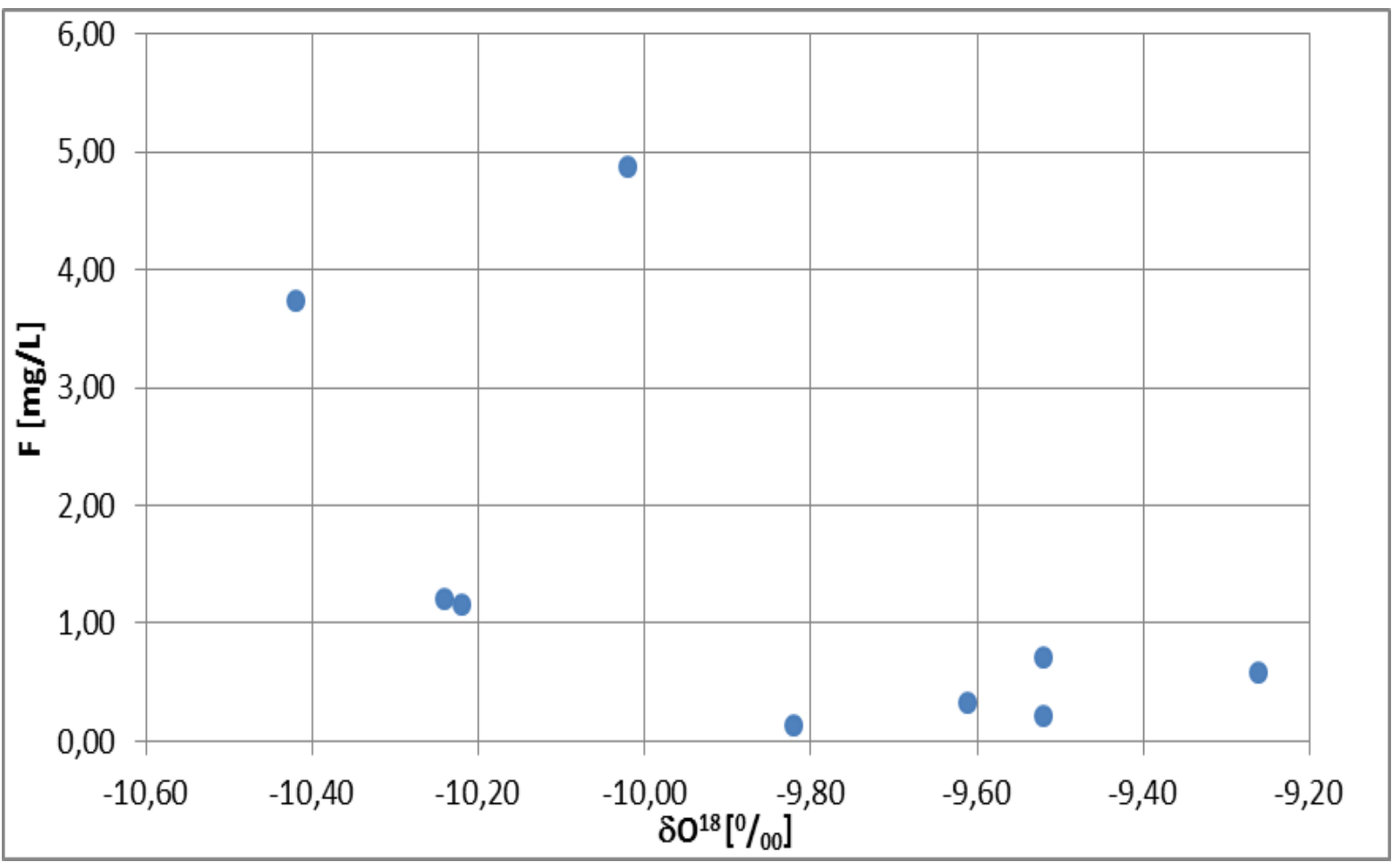

Figure 11. Fluoride concentrations in selected Neogene wells versus oxygen $\mathrm{O}^{18}$ content 


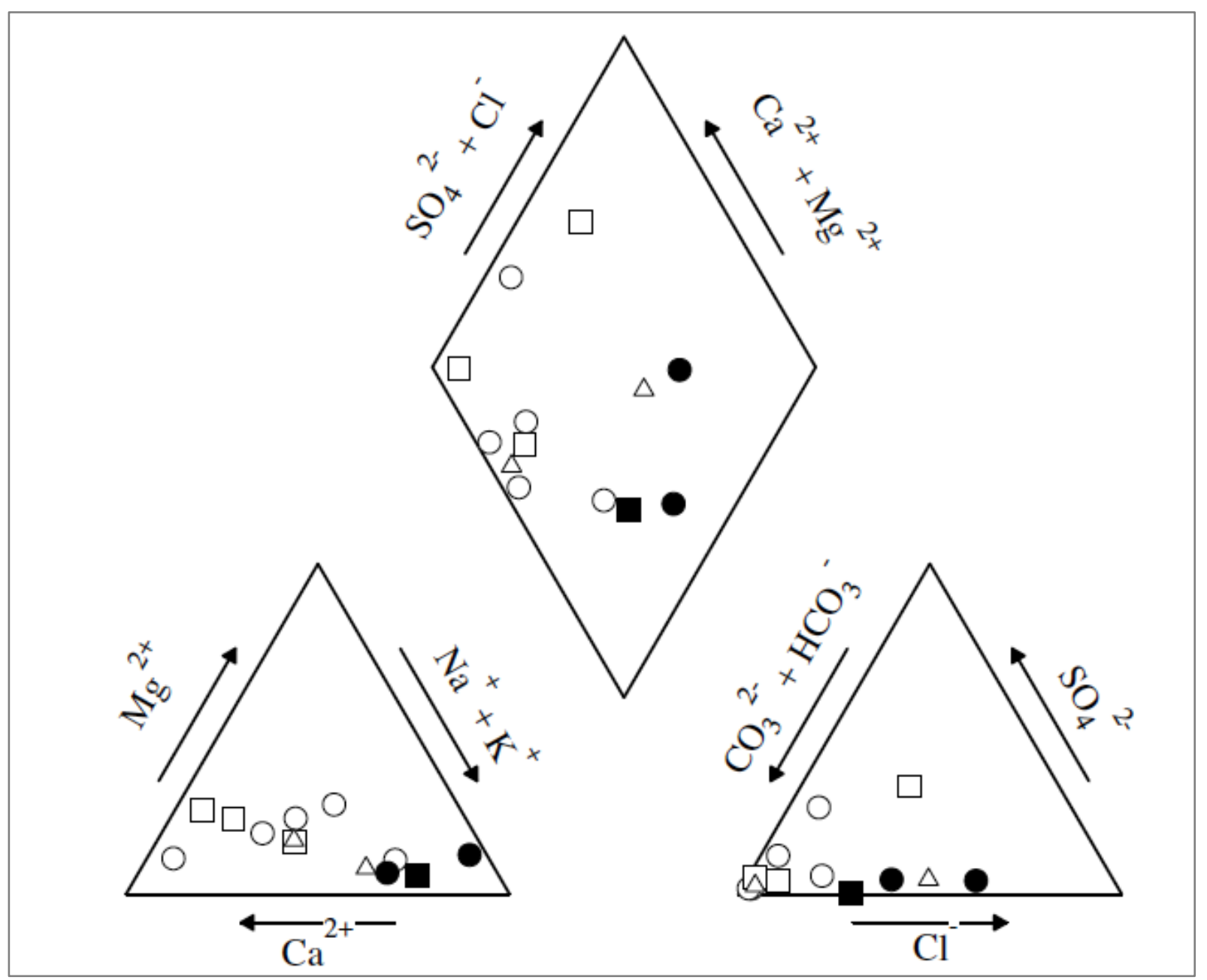

Circle - aquifer 3, square - aquifer 4, triangle - aquifer 6, black filled circle - aquifer 7, black filled square - aquifer 10.

Figure 12. Piper plot of the major cations and anions in the western part of the Neogene basin

In order to determine the source of high concentrations of fluoride in the studied waters, based on the research, hydrochemical modelling, graphs and chemical diagrams as well as the analysis of the geological structure and hydrogeological conditions, several hypotheses have been considered, such as:

- high fluoride content is associated with igneous and metamorphic rocks containing minerals rich in fluorine occurring at the bottom part of the Neogene basin and on its southern edges,

- oldest Neogene deposits were nearest to the source of weathered bedrock, therefore the lower clay units in the basin may have trapped $\mathrm{F}$ in the clay-mineral lattice, which is released due to water percolation during pumping,

- the enrichment of groundwater with fluorine was due to the short transport of the weathering products of fluorine-rich rocks and their accumulation in the inflow cones of the Miocene rivers, in a favourable climate conditions,

- location of wells with high fluoride waters near the Neogene basalt flows, since waters with high fluorine content are alkaline with elevated $\mathrm{pH}$ and $\mathrm{Na}$ content, which may suggest a source of alkaline effluent, although the strong dustiness and high content of mica minerals in the sands and gravels that build these aquifers suggest an origin from deep igneous rocks (e.g. granites) or metamorphic rocks (e.g. slates).

The most likely source of high content of fluoride in these waters is their long-term contact with the Precambrian and Palaeozoic igneous and metamorphic rocks as well as with their weathering products, containing minerals rich in fluorine. The location of fluorine anomaly is near large fault zones, which may be privileged circulation routes for waters from deep parts of the Sudetes enriched with fluorine, causing the inflow of these waters to individual aquifers of the Neogene basin.

Fluoride contents in groundwater in the Sudety Mts are generally low. Mroczkowska [26] concluded that even fluoride contents of $0.2-0.4 \mathrm{mg} / \mathrm{L}$ are anomalous, although they are much lower than those occurring in the western part of the studied Neogene basin. Only in the thermal waters of Sudetes in Lądek Spa and Cieplice Spa [10] the 
fluoride content ranges from 9.0 to $11.5 \mathrm{mg} / \mathrm{L}$ and the chemical composition of these waters is analogous to the composition of waters from aquifers 7-9 (similar $\mathrm{pH}, \mathrm{Na}$, $\mathrm{Ca}, \mathrm{Mg}$ and $\mathrm{HCO}_{3}$ ), which may indicate a similar origin water contact with intrusive (granites, syenites, trachytes) and extrusive (basalts) igneous rocks, gneisses and together with a long residence times.

Detailed chemistry studies of groundwater allowed for a relatively precise delineation of the boundary of the Neogene basin Paczków-Niemodlin. The isoline of 1.5 $\mathrm{mg} / \mathrm{L}$ fluoride content in the aquifer 4 was adopted as one of the criteria on the basis of which it was proposed to reduce the area of this Neogene basin [33]. Areas with clearly increased concentrations of fluoride in groundwater, i.e. wells in the area of Nysa, Otmuchów and Paczków are located beyond a new boundary of the basin (Fig. 13). Also the vertical range of the basin was limited by excluding the fluorine-contaminated lower aquifers of the Neogene $(7,8$, 9 and 10).

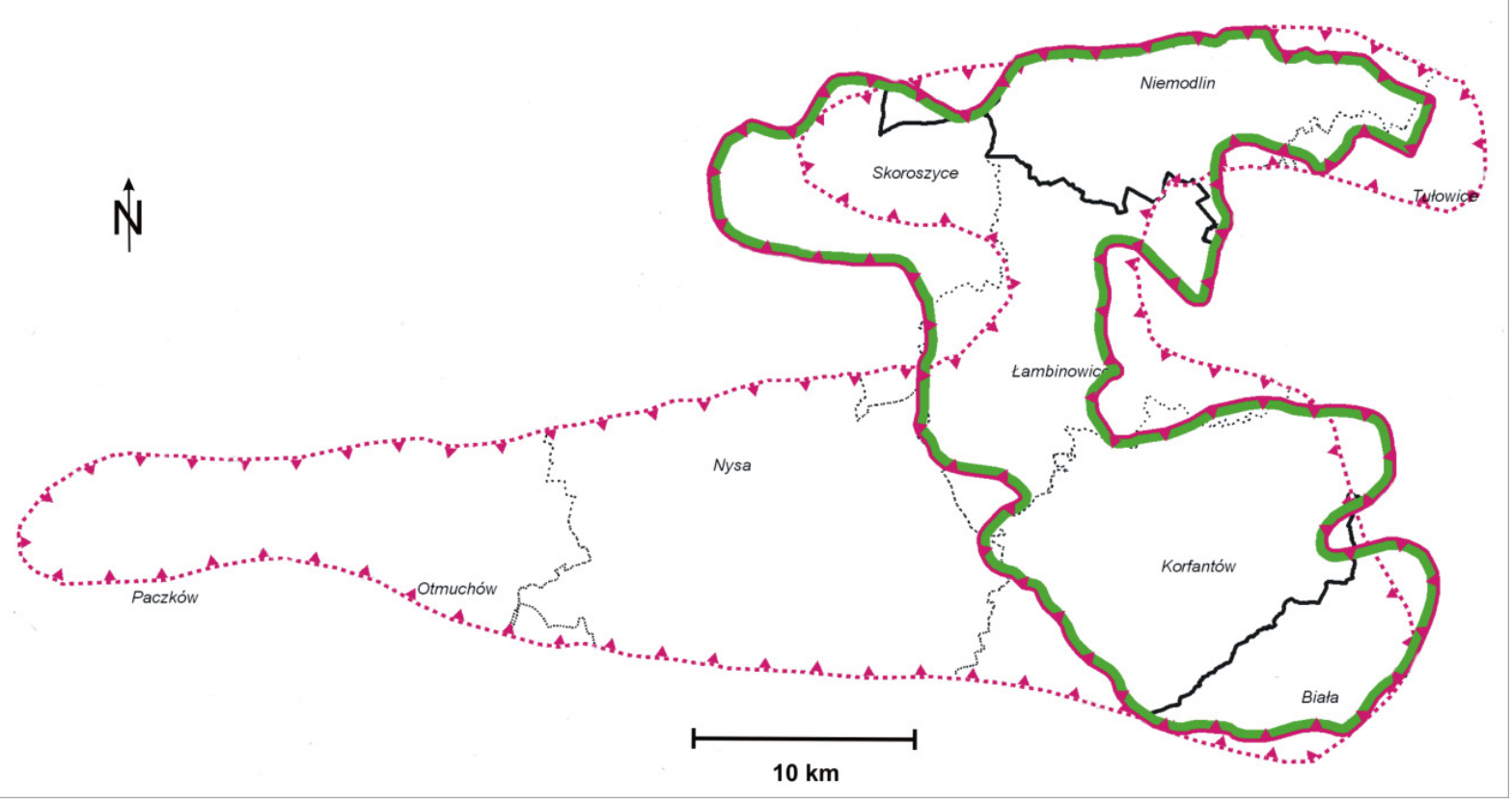

Figure 13. The Neogene Paczków-Niemodlin MGWB borders alteration due to high fluoride content. New basin border is coloured in green.

Table 7. Results of morbidity on dental fluorosis of children in Nysa town

\begin{tabular}{|c|c|c|c|c|c|}
\hline $\begin{array}{c}\text { Primary } \\
\text { School } \\
\text { No. }\end{array}$ & $\begin{array}{c}\text { Number of } \\
\text { surveyed } \\
\text { children }\end{array}$ & $\begin{array}{c}\text { Number of } \\
\text { children with } \\
\text { fluorosis }\end{array}$ & $\begin{array}{c}\text { \% of children } \\
\text { with fluorosis }\end{array}$ & $\begin{array}{c}\text { Fluoride content in } \\
\text { wells water } \\
\text { [mg/L] }\end{array}$ & $\begin{array}{c}\text { Water supply source [well no, } \\
\text { river intake] }\end{array}$ \\
\hline 1 & 184 & 58 & 31.5 & $3.7-6.3$ & $0.2-4.7$ \\
\hline 2 & 196 & 33 & 16.8 & $2.5-6.3$ & $\begin{array}{c}41,42, \\
\text { Nysa Kłodzka intake }\end{array}$ \\
\hline 3 & 398 & 189 & 47.5 & $0.2-4.9$ & $40,42,51$ \\
\hline 5 & 334 & 24.2 & $0.2-4.9$ & $\begin{array}{c}41,42, \\
\text { Nysa Kłodzka intake }\end{array}$ \\
\hline 7 & 80 & 32 & 40.0 & $3.7-6.3$ & 41,42, \\
Nysa Kłodzka intake \\
\hline 8
\end{tabular}




\subsection{Occurrence of Dental Fluorosis in Children in Nysa Area}

Due to the very high content of fluoride in groundwater, the studies of dental fluorosis were conducted in Nysa town. Before 1997, the water supply network in Nysa exploited two sources: surface intake on the Nysa Kłodzka River and the Neogene aquifer wells. At that time, the effects of long-term consumption of water rich in fluoride were studied in residents of districts of Nysa supplied with water from the Neogene wells [23]. In the inhabitants of these districts high intensity diseases such as fluorosis and osteoporosis were recognized. A detailed study of morbidity of children aged 7-15 years on fluorosis in 8 primary schools located in areas supplied by water from the Neogene wells in Nysa was carried out [23]. As a result of consumption of water with high fluoride content, damage of tooth enamel and fluorosis was observed in children. Most cases of fluorosis were observed in three schools $(3,7$, 10), which were associated with a high content of fluoride in waters from the wells, which supplied the population living in this area (Table 7).

The lowest percentage of children with fluorosis was observed in the schools, where the majority of the population was supplied with water from the surface water intake (Nysa Kłodzka). In schools, where nearly all the inhabitants consumed water from the Neogene wells with a fluoride content of 4-7 $\mathrm{mg} / \mathrm{L}$ a percentage of children with fluorosis was the highest and ranged from $47.5 \%$ to $56.6 \%$.

\section{Conclusions}

The fluoride content in groundwater in the Neogene basin Paczków-Niemodlin is high, exceeding many times the limit for drinking water with the highest concentrations in the western part of this basin. Results of studies presented in this paper confirmed the upward trend of the fluoride content with the decreasing elevation of the aquifer.

The main source of high fluoride content in waters in the Neogene aquifers in the study area is their long-term contact with Precambrian and Paleozoic igneous and metamorphic rocks containing fluorine-rich minerals. The location of fluorine anomalies is near large fault zones, which may be privileged water flowpaths from greater depths, causing the enrichment of these waters with fluorine.

In the area of Nysa town the dependence of the occurrence of dental fluorosis on the type of the consumed drinking water was observed, the higher the content of fluoride in drinking water, the greater the incidence of dental fluorosis. In schools in areas where nearly all the inhabitants used water from the Neogene wells with high fluoride content, the percentage of children with dental fluorosis was the highest.

Detailed chemistry studies for this aquifer allowed for a relatively precise delineation of the boundary of the Neogene basin "Paczków-Niemodlin". Beyond a new boundary of the basin, areas with clearly increased concentrations of fluoride in groundwater remained. The vertical range of the basin was also limited by excluding the fluorine-contaminated lower aquifers of the Neogene, no: $7,8,9$ and 10 .

The study presented in this paper has shown that in central Europe, high fluoride groundwater may cause serious risk of human health and shouldn't be disregarded during consideration of the global problem of high fluoride waters. As there are other highly productive sources of drinking waters in this region, remediation options for naturally rich in fluorine groundwater were not considered.

The results of this study should be taken into account when estimating groundwater resources and evaluating the risks and the possibilities of utilization waters from this type of the Neogene groundwater basins, not only in the studied area, but also around the world.

\section{Acknowledgements and Funding Information}

The paper is based on several fluoride water studies conducted by the authors which are not published, but cited in the references and which were financed by the Ministry of Science and Ministry of Environment in Poland.

I want to thank all the hydrogeologists from the Upper Silesian Branch of the Polish Geological Institute-PIB for their support.

\section{Conflict of Interest}

On behalf of all authors, the corresponding author states that there is no conflict of interest.

\section{REFERENCES}

[1] Ainchil K., "Fluoride in groundwater variations of an area in Buenos Aires Province, Argentina". Environmental Geology, vol. 44, pp. 86-89, 2003. DOI: $10.1007 / \mathrm{s} 00254-002-0702-0$

[2] Andezhath, S.K., Ghosh G., "Fluorosis management in India: the impact due to networking between health and rural drinking water supply agencies", Proceeding of the Santiago Symposium, IAHS Publication, vol. 260, pp. 159165,2000 .

[3] Apambire W.M., Boyle D.R., Michel F.A., "Geochemistry, genesis, and health implications of fluoriferous groundwater in the upper regions of Ghana", Environmental Geology. Vol. 35, no. 1, pp. 13-24, 1997. DOI: $10.1007 / \mathrm{S} 002540050221$

[4] Ayoob S., Gupta A.K., "Fluoride in drinking water: A 
review on the status and stress effects", Critical Reviews in Environmental Science and Technology, vol. 36, pp. 433487, 2006. DOI: 10.1080/10643380600678112

[5] Badura J., Przybylski B., "Geological Map of Poland at a scale 1: 50 000. Mapsheet Nysa", Polish Geological Institute, Warsaw, 1994

[6] Badura J., Przybylski B., "Geotectonic Map of the Lower Silesia", Polish Geological Institute, Wroclaw, 2000.

[7] Badura J., Przybylski B., "Geological Map of Poland at a scale 1: 50 000. Mapsheet Biała", Polish Geological Institute. Warsaw, 2002.

[8] Banks D., Frengstad B., Midtgard A., Reidar Krog J., Strand T., "The chemistry of Norwegian groundwater: The distribution of radon, major and minor elements in 1604 crystalline bedrock groundwater", The Science of the Total Environment, vol. 222, pp. 71-91, 1998.

[9] Chae G.T., Yun T., Mayer B., Kim K.H., Kim S.Y., Kwon J.S., Kim K., Koh Y.K., " Fluorine geochemistry in bedrock groundwater of South Korea", Science of the Total Environment, vol. 385, no. 1-3, pp. 272-283, 2007.

[10] Ciężkowski W., Gröning M., Leśniak. P.M., Weise S.M., Zuber A., "Origin and age of thermal waters in Cieplice Spa, Sudeten, Poland, Inferred from isotope, chemical and noble gas data", Journal of Hydrology, vol. 140, pp. 89-117, 1992.

[11] Dehbandi R., Moore F., Keshavarzi B., "Geochemical sources, hydrogeochemical behavior, and health assessment of fluoride in an endemic fluorosis area, central Iran risk", Chemosphere, vol. 193, pp. 763-776, 2018. DOI: 10.1016/j.chemosphere.2017.11.021

[12] Dissanayake C.B., "The fluoride problem in the ground water of Sri Lanka - environmental management and health", International Journal of Environmental Studies, vol. 38 , no. 2 , pp. $137-155$, 1991. DOI.org/10.1080/002072391 08710658

[13] Dyjor S., Dendewicz A., Grodzicki A., Sadowska A., "Neogeńska i staroplejstoceńska sedymentacja w obrębie stref zapadliskowych rowów Paczkowa i Kędzierzyna" (Neogene and early Pleistocene sedimentation within the Paczkow and Kedzierzyn Grabens), Geologica Sudetica vol.13, no. 1,1978 .

[14] Edmunds W.M., Smedley P.L., "Fluoride in natural waters", in "Essentials of Medical Geology", Elsevier Academic Press, London, 2005, pp. 301-329.

[15] Farooqi A., Masuda H., Kusakabe N., Firdous N., "Distribution of highly arsenic and fluoride contaminated groundwater from east Punjab, Pakistan, and the controlling role of anthropogenic pollutants in the natural hydrological cycle", Geochemical Journal, vol. 41, pp. 213-234, 2007. DOI: 10.2343 /geochemj.41.213

[16] Fawell J., Bailey K., Chilton J., Dahi E., Fewtrell L., Magara Y., "Fluoride in drinking water", WHO, IWA Publishing, 2006, pp. 1-144.

[17] Gaciri S.J., Davies T.C., "The occurrence and geochemistry of fluoride in some natural waters of Kenya". Journal of Hydrology, vol. 143, pp. 395-412, 1993. DOI.org/10.1016/ 0022-1694(93)90201-J
[18] HYDRO. Hydrogeological Database of Poland, http://spd.pgi.gov.pl/PSHv8/Psh.html (accessed, Oct. 1. 2021).

[19] Kim Y., Kim J.Y., Kim K., "Geochemical characteristics of fluoride in groundwater of Gimcheon, Korea: Lithogenic and agricultural origins". Environmental Earth Sciences, 2010. DOI: $10.1007 / \mathrm{s} 12665-010-0789-7$.

[20] Koślacz R., "Fluor w neogeńskich poziomach wodonośnych rejonu Nysy" (Fluoride in the Neogene aquifers in Nysa region), VI Polish-Czechoslovak Symposium: "Protecting and pollution of groundwater", Darłówek, pp. 209-216, 1989.

[21] Krauskopf K.B., Bird D.K., "An introduction to geochemistry”, McGraw-Hill Int., Singapore, 1995, 647.

[22] Li X., Hou X., Zhou Z., Liu L., "Distribution and Geochemical Evolution of Fluoride in Groundwater of Taiyuan Basin, China", ICEET '09 Proceedings of the 2009 International Conference on Energy and Environment Technology, vol. 2, pp. 507-510, 2009. DOI: 10.1109/ICEET.2009. 361

[23] Martynowicz K., "Wpływ długookresowego spożywania wody pitnej z nadmiarem fluoru na częstość występowania fluorozy" (The impact of long-term consumption of drinking water with excess fluoride on the incidence of fluorosis), Unpublished. 2000. Archive of Water Works in Nysa.

[24] Mikołajków J., Sadurski A. eds., „Główne Zbiorniki Wód Podziemnych w Polsce. Informator PSH", (Main Groundwater Basins in Poland. Polish Hydrogeological Survey), PIG-PIB, Warsaw, 2017.

[25] Monitoring of groundwater in Poland. Chief Inspectorate of Environmental Protection, http://mjwp.gios.gov.pl/wynikibadan/wyniki-badan-2020.html). (accessed Oct. 1, 2021).

[26] Mroczkowska B., "Występowanie fluoru w wodach sudeckich" (The presence of fluoride in groundwater in Sudety Mts), Unpublished, 1978. National Archive of PGI, Warsaw.

[27] Oruc N., "Occurrence and problems of high fluoride waters in Turkey: An overview", in. "Medical Geology in Developing Countries, Part 2". Environmental Geochemistry and Health, vol. 30, no 4, pp. 315-323, 2008. DOI: $10.1007 / \mathrm{s} 10653-008-9160-2$

[28] Przybylski B., Cwojdziński S., "Geological Map of Poland at a scale 1: 50 000, Mapsheet Otmuchów”, PGI, Warsaw, 2009.

[29] Rango T., Bianchini G., Beccaluva L., Tassinari R., "Geochemistry and water quality assessment of central Main Ethiopian Rift natural waters with emphasis on source and occurrence of fluoride and arsenic", Journal of African Earth Sciences vol. 57, pp. 479-491, 2010. DOI: 10.1016/j.jafrearsci.2009.12.005

[30] Razowska-Jaworek L., Cudak J., "Hydrogeological Map of Poland at a scale 1:50 000. Mapsheet Nysa", Polish Geological Institute Warsaw. 2002.

[31] Razowska-Jaworek L., Cudak J., "Fluor w wodach GZWP w Polsce. Występowanie fluoru w wodach podziemnych w zbiorniku Paczków-Niemodlin" (The presence of fluoride in groundwater basin Paczków-Niemodlin ), Unpublished 
Institute report. 2007. Polish Geological Institute. Warsaw.

[32] Razowska-Jaworek L., Cudak J.,“Geneza i rozprzestrzenienie wód w wysoką zawartością fluoru w GZWP nr 338 Paczków-Niemodlin" (Origin and distribution of high fluoride content water in the Main Groundwater Basin no 338 Paczków-Niemodlin), Bulletin PGI, vol. 436, pp. 397-402, 2009.

[33] Razowska-Jaworek L., Cudak J., Kaczorowski Z., Pasternak M., "Dokumentacja hydrogeologiczna określająca warunki hydrogeologiczne w związku $\mathrm{Z}$ ustanawianiem obszarów ochronnych Głównego Zbiornika Wód Podziemnych nr $338 \quad$ - Subzbiornik Paczków-Niemodlin", (Hydrogeological documentation of the protected areas of the Main Groundwater Basin no 338 Paczków-Niemodlin), Unpublished Institute report, 2013. Polish Geological Institute. Warsaw.

[34] Razowska-Jaworek L., Kaczorowski Z., Pasternak M., Cudak J., "Modelowanie wielowarstwowych zbiorników wodonośnych na przykładzie GZWP nr 338 - Subzbiornik Paczków-Niemodlin" (Modelling of multilayered groundwater basins on the example of MGWB no 338 Paczków-Niemodlin), Geological Review, vol. 65, no. 11(2), pp. 1234-1238, 2017.

[35] Saxena V.K., Ahmed S., "Dissolution of fluoride in groundwater: a water-rock interaction study. Environmental Geology, vol. 40, no. 9, pp. 1084-1087, 2001. DOI: $10.1007 / \mathrm{s} 002540100290$

[36] Srinivasa Rao N., "The occurrence and behaviour of fluoride in the groundwater of the Lower Vamsadhara River basin, India", Hydrological Sciences, vol. 42, no. 6, pp. 877-892, 1997.

[37] Tekle-Haimanot R., Melaku Z., Kloos H., Reimann C., Fantaye W., Zerihun L., Bjorvatn K., "The geographic distribution of fluoride in surface and groundwater in Ethiopia with an emphasis on the Rift Valley", Science of the Total Environment, vol. 367, pp. 182-190, 2006. DOI: 0.1016/j.scitotenv.2005.11.003

[38] Valenzuela-Vasquez L., Ramırez-Hernandez J., Reyes-Lopez J. et al., "The origin of fluoride in groundwater supply to Hermosillo City, Sonora, Mexico", Environmental Geology, vol. 51, pp.17-27, 2006. DOI.org/10.1007/s00254-006-0300-7

[39] Vivona R., Preziosi E., Madé B., Giuliano G., "Occurrence of minor toxic elements in volcanic-sedimentary aquifers: a case study in central Italy", Hydrogeology Journal, vol. 15, pp. 1183-1196, 2007. DOI: 10.1007/s10040-007-0169-x

[40] Whelton H.P., Ketley C.E., McSweeney F., O’Mullane D.M., "A review of fluorosis in the European Union; prevalence, risk factors and aesthetic issues", Community Dent Oral Epidemiology, vol. 32, no. 1, pp. 9-18, 2004. DOI: $10.1111 / \mathrm{j} .1600-0528.2004 .00134 . x$

[41] Witczak S., Kania J., Kmiecik E., "Katalog wybranych fizycznych i chemicznych wskaźników zanieczyszczenia wód podziemnych i metod ich oznaczania" (Catalogue of selected physical and chemical parametres of pollution of groundwater and the methods of their analysis), Fluoride, Library of Monitoring of Environment. Warsaw. 2013, pp.398-403.

[42] World Health Organization. "Revision of the WHO guidelines for drinking water quality". WHO, Geneva, Fluoride vol. 1.5, 2011.

[43] Wu J., Li P., Qian H., "Hydrochemical characterization of drinking groundwater with special reference to fluoride in an arid area of China and the control of aquifer leakage on its concentrations", Environmental Earth Sciences, vol. 73, pp.8575-8588, 2015. DOI: 10.1007/s12665-015-4018-2 